\section{Identifying Local Learning Communities During the Terminal Palaeolithic in the Southern Levant: Multi-scale 3-D Analysis of Flint Cores}

FRANCESCO VALLETTA (1)

ITAMAR DAG

LEORE GROSMAN (1)

*Author affiliations can be found in the back matter of this article
CORRESPONDING AUTHOR:

\section{Francesco Valletta}

The Hebrew University of Jerusalem, IL

francesc.valletta@mail.huji.ac.il

\section{KEYWORDS:}

Southern Levant; Upper Palaeolithic; Epipalaeolithic; Lithic technology; 3-D models; Quantitative Features

TO CITE THIS ARTICLE: Valletta, F, Dag, I and Grosman, L. 2021. Identifying Local Learning Communities During the Terminal Palaeolithic in the Southern Levant: Multi-scale 3-D Analysis of Flint Cores. Journal of Computer Applications in Archaeology, 4(1), 145-168. DOI: https://doi.org/10.5334/ jcaa. 74 


\section{INTRODUCTION}

The present paper focuses on population dynamics during the later stages of the Upper Palaeolithic (LUP; ca. 30,000-24,000 cal BP) and the pre-Natufian Epipalaeolithic (EP; ca. 24,000-15,000 cal BP) in the Southern Levant. Lacking deeply stratified sequences and a robust chronological framework, our knowledge of the LUP remains incomplete, with few clearly defined archaeological entities (Belfer-Cohen \& Goring-Morris 2003, 2014, 2017; Gilead 1991). On the other hand, the EP provides a relatively high resolution archaeological record for defining cultural changes, especially due to the appearance of microliths: standardized, minute lithic implements (Belfer-Cohen \& Goring-Morris 2002). Patterns in the type of microliths produced and in other stylistic traits allow us to define a series of geographically and chronologically limited cultural entities within the EP (Bar-Yosef 1970; Belfer-Cohen \& Goring-Morris 2014; Byrd 1988; Goring-Morris 1987; Goring-Morris \& BelferCohen 2017).

Alongside the lithic evidence, the EP archaeological record is characterized by a progressive increase in the importance of smaller ungulates and lower ranked prey in the faunal assemblages (Munro 2009b, 2009a; Munro et al. 2018; Stiner 2001; Stiner, Munro \& Surovell 2000; Stutz, Munro \& Bar-Oz 2009; Zeder 2012), by the development of ground-stone tools and possible plant cultivation (Dubreuil \& Nadel 2015; Nadel et al. 2012; Snir et al. 2015; cf. Abbo \& Gopher 2020), by the appearance of cemeteries (Bocquentin et al. 2011; Maher et al. 2011), and by the increased production of mobile art (Hovers 1990; Kaufman et al. 2017; Shimelmitz et al. 2018; Yaroshevich et al. 2016). The greater investment in stylistic behavior (Sackett 1982, 1986; Wobst 1977) suggested by increasingly pronounced technological and typological differences, decorated items, and symbolism, combined with the intensification in the exploitation of local resources highlights a positive trend in population density, possibly corresponding to increased awareness of group identity and territoriality (Belfer-Cohen \& Goring-Morris 2003; Maher, Richter \& Stock 2012; Rosenberg 1990,1998). The precise timing and modes of these developments are yet to be established. Based on traditional analysis of archaeological assemblages it is difficult to detect the scale and nature of the relationship between landscape and specific human groups.

The aim of this study is to test possible local learning communities that repeatedly occupied specific areas of the Southern Levant. Learning communities are defined as uninterrupted chains of teachers and learners, along which technological knowledge is directly transmitted from one generation to the subsequent through instruction and/or imitation. These communities have previously been referred to with different terminologies, including 'populations' (Cavalli-Sforza et al. 1982) and 'societies' (Borgerhoff Mulder, Nunn \& Towner 2006). Technological and typological aspects of lithic assemblages reflect cultural traits (Lyman \& O'Brien 2003) that can be transmitted either vertically within a specific learning community, or horizontally among neighboring communities (Borgerhoff Mulder, Nunn \& Towner 2006; Eerkens \& Lipo 2007). Traits that are less visible to external individuals (low visibility) and require a longer and more complex learning process (technologically rigid) are more likely to be vertically transmitted and, consequently, to be retained within the community than more visible and technologically malleable ones (Gosselain 2000; Premo \& Tostevin 2016). Consequently, continuity among lithic assemblages in less visible and malleable traits can be related to a greater degree of cultural intimacy between the groups that produced them, while more visible and malleable traits can be more easily transmitted among separated communities belonging to the same geographically wide-spread network.

LUP and EP cultural entities are traditionally defined based on highly visible and technologically malleable typological traits (Bar-Yosef 1970; Goring-Morris 1987), thus, likely representing widespread networks of interconnected learning communities. On the other hand, technological traits of the reduction sequence are barely visible outside the restricted knapper group and their transmission involves a greater investment of time, energy, and material (Hiscock 2014). These less visible and less malleable traits are therefore, more likely to be maintained within a specific community and can be used to track local populations.

Local learning communities were previously defined within the geographically widespread LUP and EP cultural entities based on variability in the typological composition of the microlith assemblages (Bar-Yosef 1981; Goring-Morris 2009; Goring-Morris, Hovers \& BelferCohen 2009), or on lower visibility traits such as microlith size (Goring-Morris 1987; Kadowaki \& Nishiaki 2016), morphology, use (Macdonald 2013), and core reduction method (Marder 2002). Additionally, our previous study on sites attributed to different cultural entities in a geographically limited area (Ein Gev, Valletta \& Grosman 2021) highlighted traits of the core reduction method that locally outlasted typologically defined cultural entities, allowing us to track communities that maintained their own manufacturing tradition, despite adopting novel typological traits. The present study extends this analysis by adding the geographical comparison with coeval sites from a different area (Sharon Plain) and by including technological traits that might have been transmitted through interaction on different scales inside and outside specific learning communities.

The Sharon Plain is ca. $90 \mathrm{~km}$ from Ein Gev, corresponding to the roaming territories proposed for EP human groups (Byrd, Garrard \& Brandy 2016; Goring-Morris 2009; Goring-Morris, Hovers \& Belfer- 
Cohen 2009). Continuity of technological traits between the two areas may, thus, be related to the wide-range mobility of a single community, or to a geographically widespread manufacturing tradition, shared by different interconnected groups. On the other hand, geographically discontinuous technological traits may possibly represent specific communities that over long time spans repeatedly occupied the same areas.

\section{CULTURAL ENTITIES AND SITES}

We analyzed six collections of cores from different sites in two areas of the Mediterranean sub-region of the Southern Levant: Ein Gev and the Sharon Plain. Ein Gev is situated on the Eastern shore of the Sea of Galilee in the upper Jordan Valley, while the Sharon Plain, a ca. 90 by $15 \mathrm{~km}$ flat area, is bordered by Mount Carmel to the North, the Yarkon river to the South, the Nablus/Samarian hills to the East and the Mediterranean Sea to the West (Figure 1).

Based on their typological composition and on other high-visibility stylistic traits, assemblages are attributed to the UP Atlitian and to the EP Nizzanan, Kebaran, and Geometric Kebaran cultural entities (Figure 2):

- The Atlitian cultural entity is present in the Mediterranean sub-region of the Levant and dated between ca. 27,000-26,000 cal BP. It includes two categories of lithic assemblages: those rich in bladelets and bladelet cores and those dominated by burins on Clactonian truncations/notches with few bladelets and microliths (Belfer-Cohen et al. 2004; Belfer-Cohen \& Goring-Morris 2003, 2014, 2017).

- The Kebaran cultural entity occurs in most of the Western Levant, including Mediterranean and arid environments (Bar-Yosef 1970; Goring-Morris 1987). It is typically dated between ca. 21,000-18,000 cal BP (Goring-Morris \& Belfer-Cohen 2017), yet a series of earlier dates (up to ca. 24,000 cal BP) are available for assemblages attributed to this culture (Edwards, Macumber \& John Head 1996; Garrard \& Byrd 2013; Shimelmitz et al. 2018). Kebaran lithic assemblages are characterized by the production of non-geometric microliths, especially micropoints and obliquely truncated and backed bladelets (Kebara points), without microburin technique (MbT). The Kebaran cultural entity was also subdivided into an Early (dominated by micropoints) and a Late (dominated by Kebara points) phase (Bar-Yosef 1981).

- The Nizzanan cultural entity, dated between ca. 20,000-18,500 cal BP, is broadly coeval to the Kebaran (Byrd \& Garrard 2017; Goring-Morris \& Belfer-Cohen 2017) and is found throughout the Southern Levant (Bar-Yosef 1970; Garrard \& Byrd 2013; Goring-Morris 1987; Saxon, Martin \& Bar-Yosef 1978). The most common microliths are small- and medium-sized triangles (scalene bladelets) and

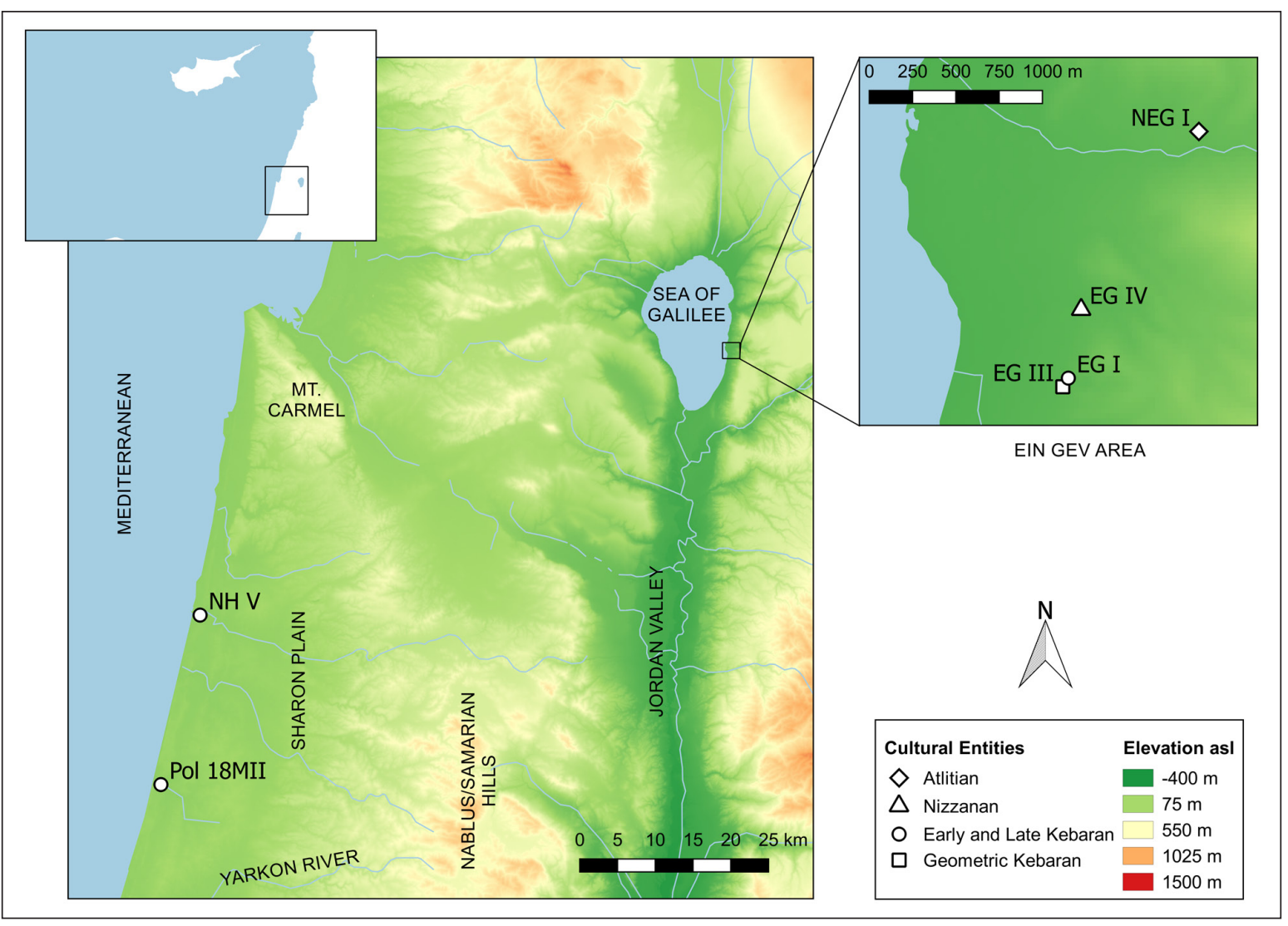

Figure 1 Location of the analyzed sites. 


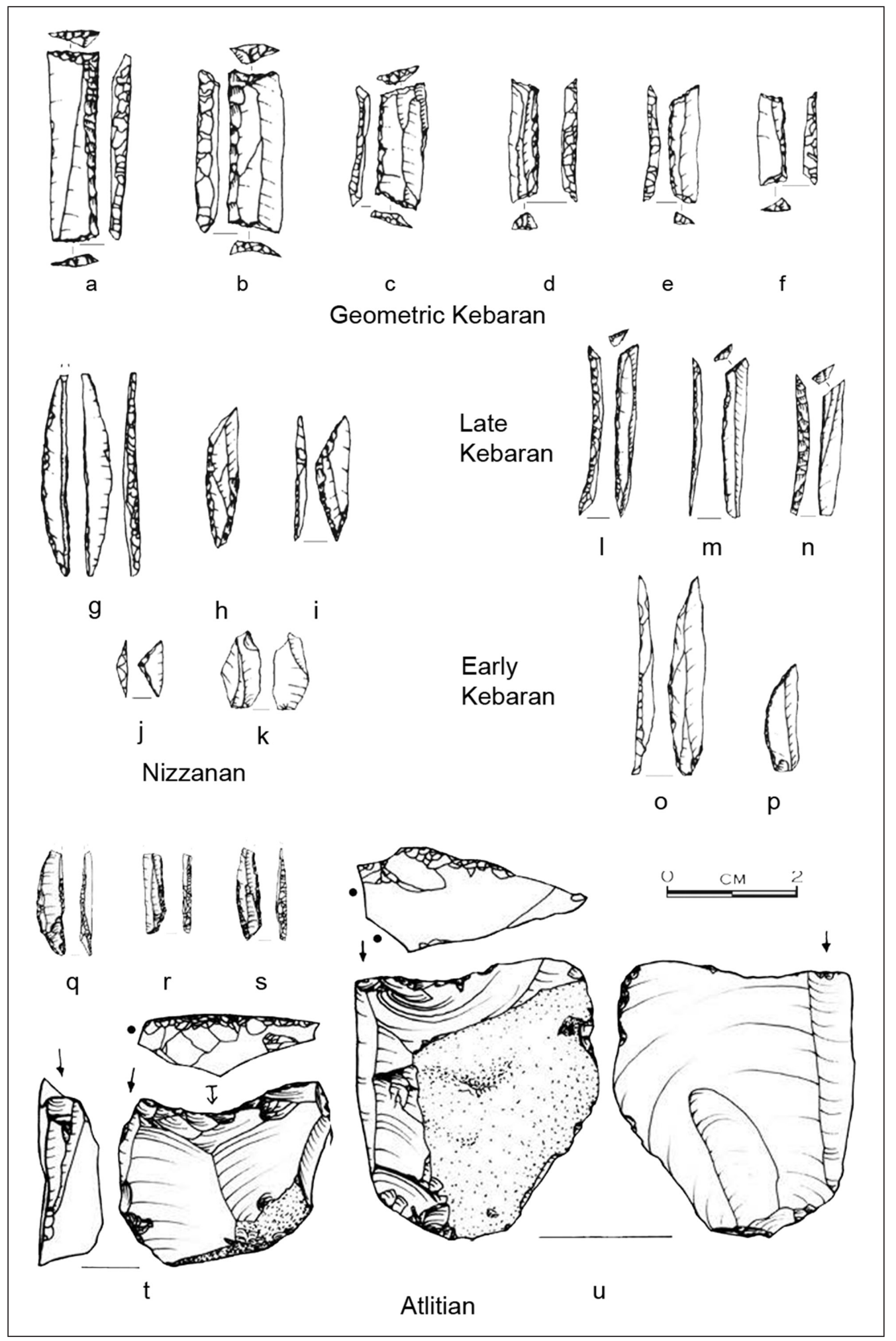

Figure 2 Selected lithic tools that typify each cultural entity: Geometric Kebaran: trapeze-rectangles (a-f); Nizzanan: microgravette (g), scalene bladelets truncated by MbT (h) and abrupt retouch (i), triangle (j), and microburin (by-product of the MbT - k); Late Kebaran: backed and obliquely-truncated bladelets (Kebara points - (-n); Early Kebaran: micropoints (o, p); Atlitian: backed microliths (q-s) and burins on Clactonian truncation (t, u). After Belfer-Cohen and Goring-Morris (2014, 2017).

microgravettes. Oblique truncations on bladelets are systematically obtained with MbT.

- The Geometric Kebaran cultural entity is dated between ca. 18,500-15,000 cal BP and it is encountered in most of the Southern and Northern Levant (Goring-Morris \& Belfer-Cohen 2017). Microlith assemblages are dominated by trapeze-rectangles, manufactured without the use of MbT.

\subsection{EIN GEV AREA}

The earliest assemblage included in the study is from Nahal Ein Gev I (NEG I). The site was discovered in 1971 
and the articulated burial of a 30-35 year old woman was recovered alongside lithic artifacts (Arensburg 1977; Bar-Yosef 1973, in Hebrew). Further investigation was conducted in 1993, with the aim of testing the extension of the site and the presence of possible later disturbances (Belfer-Cohen et al. 2004). The lack of suitable charcoal samples resulted in no absolute radiometric dates available for the site. However, based on the abundance of burins on truncations and carinated scrapers, and on the flake-oriented reduction sequence, the occupation of this site is attributed to the Atlitian cultural entity (BelferCohen et al. 2004).

Subsequent occupation of the area is represented by the sites of Ein Gev I (EG I) and Ein Gev IV (EG IV). Fieldwork at EG I exposed a hut of 5-7 $\mathrm{m}$ in diameter, with a stratigraphic sequence of six subsequent livingfloors. The articulated burial of a 30-40 year old woman was found related to one of the living-floors (Arensburg \& Bar-Yosef 1973; Bar-Yosef 1970; Trinkaus 2018). Based on the typological composition of the microlith assemblages (mostly backed and obliquely truncated bladelets) and on one available radiometric date (GrN-5576: 15,700 \pm 415 BP; 20,000-18,100 cal BP - 2 $\sigma$; CALIB v. 8.2; Stuiver, Reimer \& Reimer 2021), it was possible to attribute the occupation of the site to the Late Kebaran. In addition to the burial and lithic assemblages, the site returned a rich faunal assemblage (Davis 1974; Marom \& Bar-Oz 2008).

The site of EG IV was first discovered in 1968. Archaeological investigation was limited to a $2 \mathrm{~m}^{2}$ testpit that exposed a stratigraphic sequence of five layers and, possibly, part of an architectural structure similar to that in EG I (Bar-Yosef 1970). Renewed excavations were conducted in 2016 by two of the authors (LG, FV), indicating that the deposit may extend over $500 \mathrm{~m}^{2}$. The high incidence of microgravettes and triangles in the microlith assemblage, as well as the systematic use of MbT, assigns the occupation of EG IV to the Nizzanan cultural entity (Bar-Yosef 1970; Goring-Morris 1987; Henry 1974; Valletta \& Grosman 2021).

The later pre-Natufian occupation of the Ein Gev area is represented by the site of Ein Gev III (EG III - BarYosef 1970; Martin \& Bar-Yosef 1975, 1979). Fieldwork highlighted three subsequent living-floors, each featuring stone architectural structures (Martin \& Bar-Yosef 1979). Based on the typological composition of the microlith assemblage, the occupation of the site was attributed to the Geometric Kebaran cultural entity.

\subsection{SHARON PLAIN}

The Poleg 18MII (Pol 18MII) lithic assemblage is the result of the systematic collection of the lithic artifacts from the surface of a hamra hill exposed by the windactivated westward progression of a sand dune. Despite lacking absolute dating and further contextual information, the typological homogeneity of the tool assemblage, dominated by non-geometric microliths (especially narrow micro-points), supports its attribution to the Early Kebaran. The reduction sequence was focused on the production of bladelets from narrow, carinated cores, obtained from tabular chunks of flint (Bar-Yosef 1970: 68-72).

The Nahal Hadera V (NH V) site was first excavated only in a $3 \mathrm{~m}^{2}$ test-pit (Saxon, Martin \& Bar-Yosef 1978), but later excavation revealed that the site extended over $500 \mathrm{~m}^{2}$ (Barkai \& Gopher 2001). Extensive excavation exposed a series of habitation levels, characterized by concentrations of bones, flints and ground-stone artifacts. A large, basin-shape depression bordered with calcarenite (kurkar) slabs in the uppermost layer was interpreted as the base of a hut (Barkai \& Gopher 2001). The core sample included in this study originates from Layer 175, attributed to the Late Kebaran based on the dominance of backed and truncated bladelets in the microlith assemblage (Shimelmitz 2002). The reduction sequence focused on the extraction of bladelets with straight profiles from narrow fronted cores. This narrow reduction surface was either obtained by exploiting the natural oval shape of pebbles or by removing thinning flakes in the core-shaping stage (Shimelmitz 2002). The direct optical dating (OSL) of the layer is between 20.3 and $18.3 \mathrm{ka}$ which is consistent with the typological attribution to a late phase of the Kebaran cultural entity (Godfrey-Smith et al. 2003).

The goal of the present study is to try and identify local learning communities based on traits of their lithic technology. Yet, culturally transmitted traits are only one of the factors affecting technological choices in the manufacturing of lithic tools (Machin 2009), including available resources, practical necessities of the knapper, and other economic aspects (Bleed 2001; Shott 2003; Soressi \& Geneste 2011; Tostevin 2011). Several lithic and non-lithic aspects of the archaeological record (Table 1) suggest a similar residential nature for the occupations of all the sites: all sites but EG III are characterized by diverse lithic tool assemblages, including different macrolithic categories (Bar-Yosef 1970; Belfer-Cohen et al. 2004; Shimelmitz 2002), suggesting that a wide range of activities were performed. The rich and diverse faunal assemblages retrieved from all sites but Pol 18MII (Bar-Oz \& Dayan 2002; Bar-Yosef 1970; Belfer-Cohen et al. 2004; Davis 1974; Davis, Rabinovich \& Goren-Inbar 1988; Marom \& Bar-Oz 2008), the dwelling structures in EG I and NH V (Bar-Yosef 1970; Barkai \& Gopher 2001; Martin \& Bar-Yosef 1979), and the burials from EG I and NEG I (Arensburg 1977; Arensburg \& Bar-Yosef 1973) further support the residential nature of the occupations. NEG I and Pol 18MII present only few of the traits, yet their diverse lithic assemblages and the rich faunal assemblage of NEG I point to the residential nature of their occupations. Other relevant traits might have been 


\begin{tabular}{lllllll}
\hline & NEG I & EG IV & EG I & EG III & POL 18MII & NH V \\
\hline Diverse lithic assemblage & $\mathrm{x}$ & $\mathrm{x}$ & $\mathrm{x}$ & - & $\mathrm{x}$ & $\mathrm{x}$ \\
\hline Diverse faunal assemblage & $\mathrm{x}$ & $\mathrm{x}$ & $\mathrm{x}$ & $\mathrm{x}$ & - & $\mathrm{x}$ \\
\hline Dwelling structures & - & $\mathrm{x}$ & $\mathrm{x}$ & $\mathrm{x}$ & - & $\mathrm{x}$ \\
\hline Ground-stone tools & - & - & $\mathrm{x}$ & $\mathrm{x}$ & - & $\mathrm{x}$ \\
\hline Burials & $\mathrm{x}$ & - & $\mathrm{x}$ & - & - & - \\
\hline
\end{tabular}

Table 1 Traits of the six archaeological assemblages suggesting residential occupation of the sites.

obliterated by the taphonomic processes that affected these sites (erosion of most of the original deposit of NEG I, deflation and possible secondary transport in Pol 18MII). All sites were, thus, likely occupied as residential camps, in which a wide range of subsistence activities were performed. Consequently, possible technological variability among the reduction sequences does not reflect different specific tasks performed within the sites and is possibly related to different manufacturing traditions. Another possible source of variability may be the lithic raw material availability (Brantingham 2003, 2006; Pop 2016). No systematic survey aimed at defining the raw material availability in the study areas has yet been performed.

\section{METHODS}

In traditional technological analyses of lithic assemblages (Andrefsky 2005, 2009; Bleed 2001; Shott 2003; Soressi \& Geneste 2011; Tostevin 2011), continuity among reduction sequences is established based on quantitative and qualitative attributes of the lithic artifacts. Possible ambiguity in the positioning of cores (Andrefsky 2005) limits the descriptive power of the linear measurements traditionally included in the analyses of this class of artifacts (e.g., length, width, and thickness). A more detailed typification of the reduction sequences of the UP and EP blade(let) cores is often obtained based on the qualitative account of features such as the position of the remaining original surface of the raw material nodule (cortex), the number and relative position of reduction surfaces and striking platforms, the distribution pattern of production and maintenance scars, and the presence of stigmata of determinate technical behaviors (e.g., platform abrasion).

In recent years, the use of digital 3-D models of lithic artifacts has improved the accuracy and objectivity of traditionally measured attributes and provided novel measurements that are impossible to obtain by hand (Grosman 2016). In many cases, attention is paid to global features that characterize the artifacts as a whole, including center of mass (Grosman, Goldsmith \& Smilansky 2011; Grosman, Smikt \& Smilansky
2008), artifact symmetry (Chacón et al. 2016; Feizi, Vahdati Nasab \& Wynn 2018; Grosman et al. 2011), outline roughness (Grosman et al. 2011), geometric morphometrics (Archer et al. 2015, 2016; Delpiano \& Uthmeier 2020; Herzlinger \& Goren-Inbar 2019a, 2019b; Lycett \& Von Cramon-Taubadel 2013; Presnyakova et al. 2018; Shott \& Trail 2010), distribution of thickness (Weiss et al. 2018), and planar symmetry (Gingerich et al. 2014; Ranhorn et al. 2019; Sholts et al. 2012, 2017). In contrast to these global features, local features have been measured based on relevant points, lines, and areas on the artifact surface of digital 3-D models (Archer et al. 2016, 2018; Bretzke \& Conard 2012; Delpiano \& Uthmeier 2020; Morales, Lorenzo \& Vergès 2015; Porter, Roussel \& Soressi 2019; Presnyakova et al. 2018; Ranhorn et al. 2019; Valletta et al. 2020; Viallet 2019; Weiss et al. 2018; Zaidner \& Grosman 2015). While these data are more precise than those based on manual measurements, their objectivity and repeatability is limited by possible ambiguities in artifact positioning and/or in the surface segments on which the measurement is performed.

A set of novel digital tools is here introduced for measuring traditionally qualitatively accounted local features of lithic artifacts (supplementary file 74-16751-SP.docx). To increase the objectivity of this process, we used a procedure for defining relevant segments based on the distribution of curvature on the surface of lithic artifacts (Richardson et al. 2013; Figure 3). The parameters introduced in the present study possess different levels of technological malleability and visibility, and therefore, may be differently transmitted between communities (Gosselain 2000; Premo \& Tostevin 2016).

- Core reduction modality is calculated as the ratio between width of the reduction surface and core thickness (W/T), measured along main technological axes defined based on the average normal of the scars corresponding to the striking platform and the blank removals (Figure 4a).

- The longitudinal profile of each blank scar is calculated as the average angle between the most regular portion of the relative striking platform and different, consecutive portions of the blank 


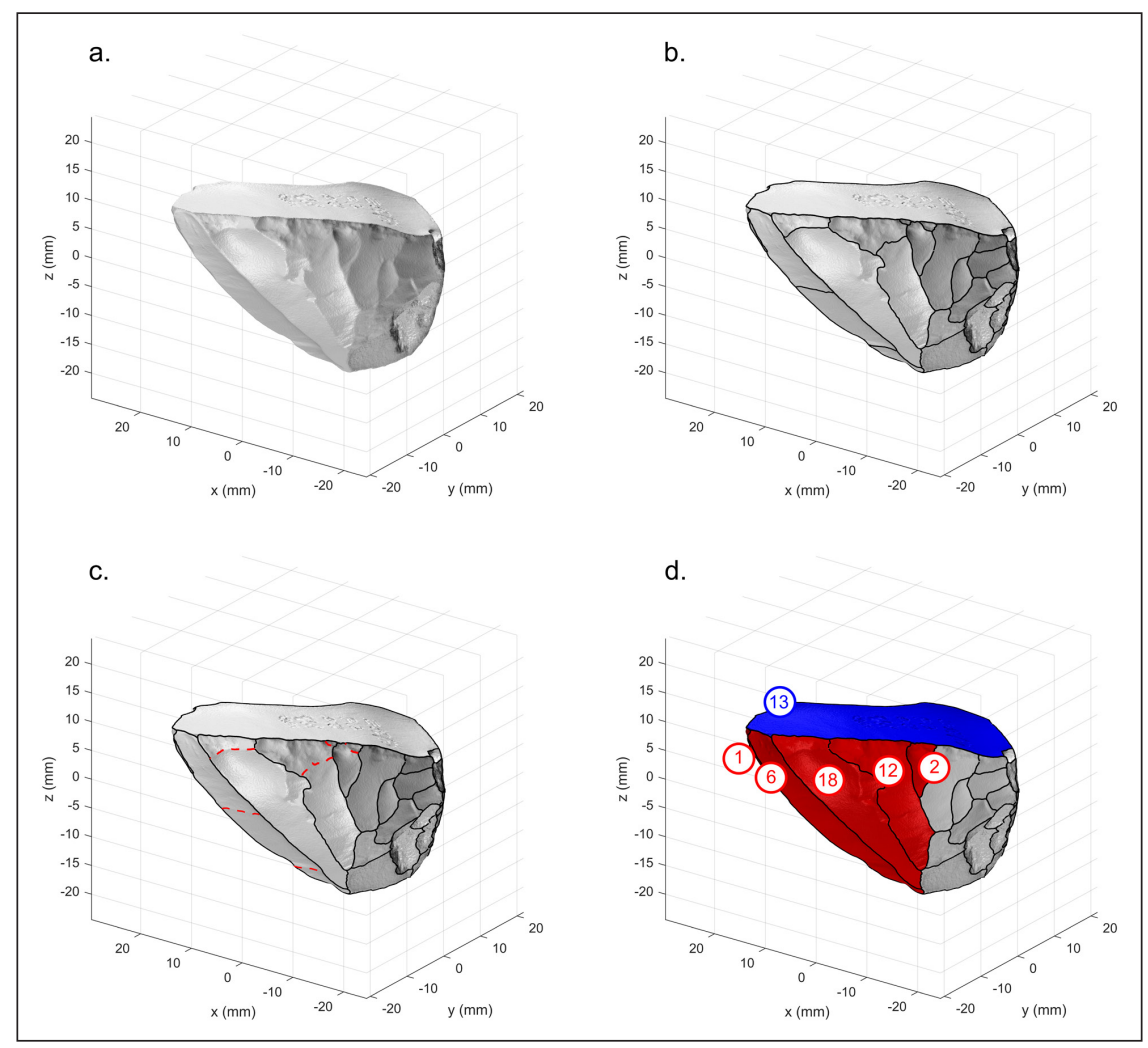

Figure 3 Procedure for defining technologically relevant segments on 3-D models. Digital 3-D model of a bladelet core (a); automatic segmentation of the core surface in scars (b); manual merging of over-segmented scars denoted by red dashed lines (c); selection of blank scars (red) and relative striking platform (blue); reported are the scar ID numbers automatically generated during the segmentation process (d).

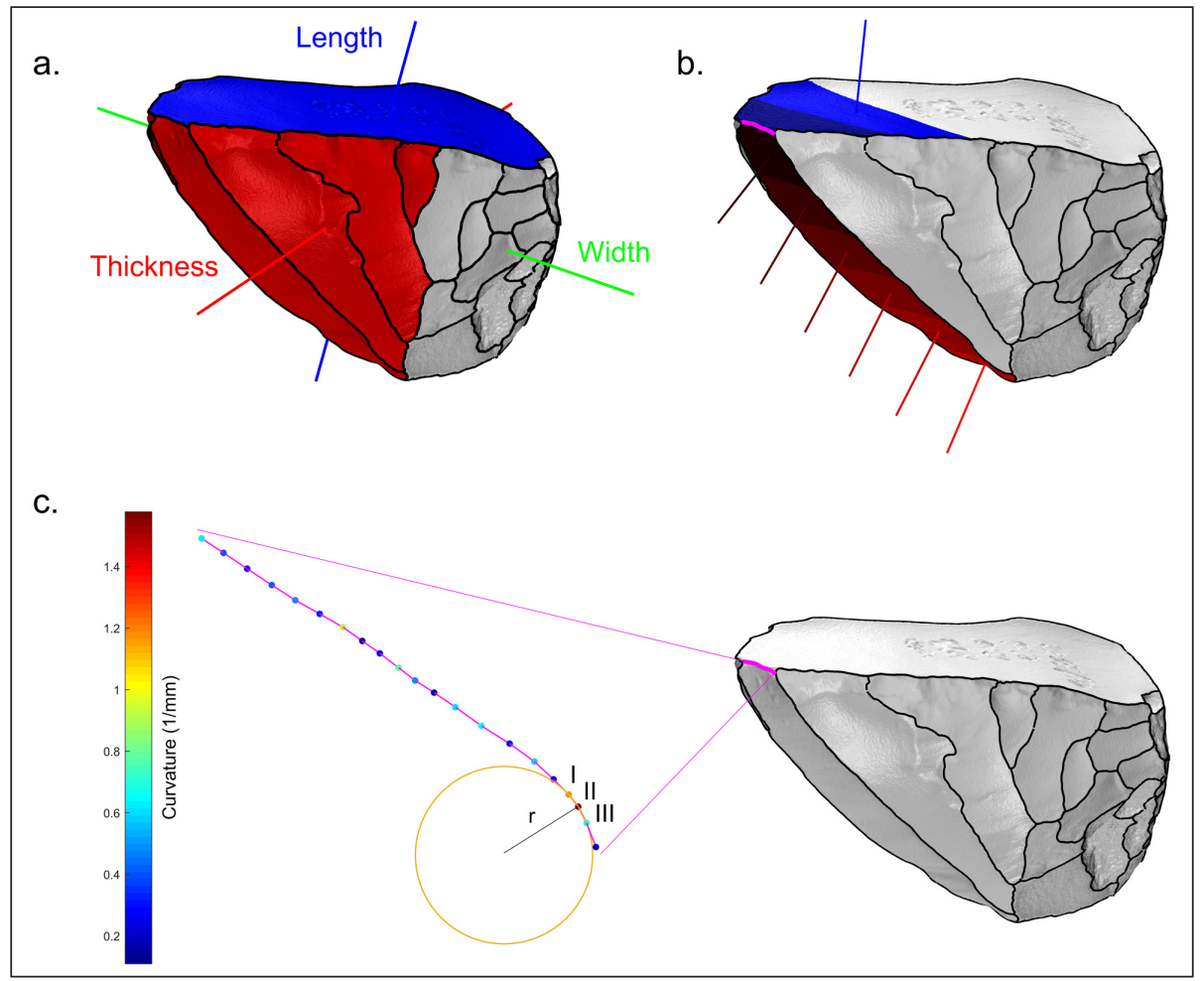

Figure 4 Measuring procedures introduced in the present work. Core reduction modality (a) measured based on linear measurements along objectively defined technological axes; blank scar profile (b) based on the average angle between each consecutive band of the blank (different shades of red) and the most regular portion of the striking platform (blue); intensity of platform abrasion (c) based on the average curvature of the ridge between a blank scar and its relative striking platform. The curvature value of each point (II) is calculated based on the radius ( $r$ ) of the circumference passing through it and its immediately neighboring points (I and III). Different curvature values are color-coded. 
scar surface (Consecutive Platform Angles - CPA; Figure $4 b$ ). Angles were calculated with a procedure derived from the one proposed by Valletta et al. (2020).

- Finally, the intensity of platform abrasion is measured based on the average curvature (AC) of the ridge between each blank scar and the relative striking platform (Figure 4c).

Additionally, the univocal definition of technologically relevant scars allows the automatic extraction of linear measurements for each blank scar and to sort them based on their length and width.

The procedures for extracting technological parameters based on 3-D models of cores are included in the Artifact3-D program (Grosman 2016; Grosman et al. in preparation), freely available upon request from the Computational Archaeology Laboratory, the Institute of Archaeology, the Hebrew University of Jerusalem and are available at an online repository (https://github.com/ itamardag/CoreAnalysisToolbox). The quantitative nature of the obtained data allowed, for each feature, to compare the assemblages pairwise based on the non-parametric rank-sum test (Wilcoxon 1945, 1946 - performed with the ranksum function, available in the Matlab ${ }^{\circledR}$ Statistics and Machine Learning toolbox). We hope that in future research the parameters introduced here will be complemented by additional ones, extending the quantitative approach to other technological traits of the reduction sequence.

\section{RESULTS}

A total of 402 cores were analyzed, including 469 striking platform-reduction surface pairs and 1,332 blank scars (Table 2). Only complete blade and bladelet cores exploited from one or two well-defined striking platforms were included in the sample, excluding multi-platform, opportunistically exploited, amorphous, and fragmentary cores. Due to the large size of the assemblages, cores from EG I and NH V were further sampled based on their context within the sites. EG I cores come from one square meter within Layer III and two square meters within Layer IV. In NH V, cores were sampled from six loci (bone and artifact concentrations) (Shimelmitz 2002) within Layer 175 and from the material without an assigned locus in a band of three square meters of the same layer. The original 3-D models used for the present analysis, their segmentation in scars, and the extracted measurements are available at an online repository (https://doi.org/10.7910/DVN/2TAL6J).

\subsection{BLANK SCAR SIZE}

In all assemblages, the length of most blank scars ranges from 21 to $49 \mathrm{~mm}$ (Figure 5; Table 3; length is calculated based on $7 \mathrm{~mm}$ bands, the result is thus a multiple of 7). Although marked differences can be observed in the blank scar widths, most blank scars are narrower than $15 \mathrm{~mm}$. This range suggests that small blanks were the main goal of the reduction sequence in all assemblages. The analysis of blank scar parameters was performed only on scars with lengths between 21-49 mm (CPA) and widths < $15 \mathrm{~mm}$ (CPA and AC) to conform to this observed production pattern.

\begin{tabular}{llll}
\hline & CORES & PLATFORMS & BLANK SCARS* \\
\hline EG I & 105 & 115 & 373 \\
\hline EG III & 32 & 34 & 83 \\
\hline NEG I & 68 & 77 & 254 \\
\hline EG IV & 30 & 32 & 94 \\
\hline Pol 18MII & 54 & 60 & 153 \\
\hline NH V & 113 & 151 & 375 \\
\hline Total & 402 & 469 & 1332 \\
\hline
\end{tabular}

Table 2 Number of cores, striking platforms, and blank scars included in each site.

* The number of blank scars included in the analysis for each platform does not necessarily correspond to the real number of scars visible on the reduction surface. In some cases, scars did not share a ridge with the platform and were excluded. In addition, the automatic segmentation did not always separate the scars. Some segments may, thus, include more than one scar.

\begin{tabular}{lllllll}
\hline & MEAN L. (MM) & MEDIAN L. (MM) & L. SD (MM) & MEAN W. (MM) & MEDIAN W. (MM) & W. SD (MM) \\
\hline EG I & 31.57 & 28 & 11.78 & 8.70 & 7.84 & 4.51 \\
\hline EG III & 33.82 & 28 & 12.07 & 8.75 & 7.86 & 4.25 \\
\hline NEG I & 38.47 & 35 & 14.61 & 11.70 & 10.33 & 6.51 \\
\hline EG IV & 37.46 & 35 & 15.69 & 9.62 & 8.78 & 4.26 \\
\hline Pol 18MII & 24.48 & 28 & 6.87 & 5.10 & 4.55 & 2.81 \\
\hline NH V & 27.42 & 28 & 9.88 & 5.63 & 5.06 & 2.85 \\
\hline
\end{tabular}

Table 3 Average, median, and standard deviation of blank scar length (L) and width (W). 


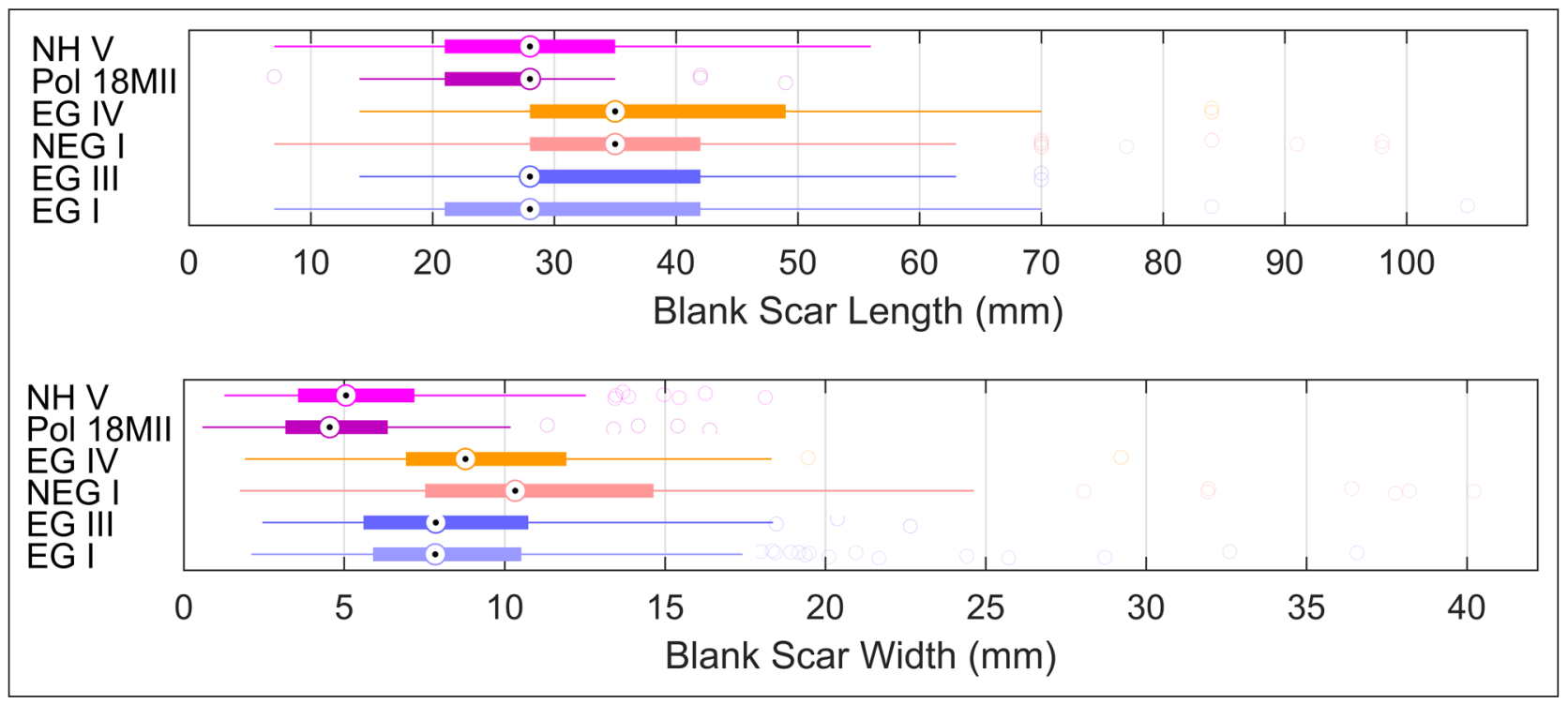

Figure 5 Boxplots of the linear measurements of blank scars. The central mark indicates the median, the bottom and top edges of the box indicate respectively the $25^{\text {th }}$ and $75^{\text {th }}$ percentiles, the whiskers extend to the most extreme data points not considered outliers (i.e., values more than 1.5 times the interquartile range away from the bottom or top of the box), and the circles indicate the outliers.

\subsection{REDUCTION MODALITY}

The exploitation modality of each platform was ranked according to the ratio between the width of the reduction surface and the core thickness (W/T), allowing an objective and repeatable classification of wide (higher ratio) and narrow-fronted (lower ratio) reduction modalities (Table 4, Figure 6).

Cores in Kebaran (Pol 18MII, NH V, and EGI) and Geometric Kebaran (EG III) assemblages present, on average, a low $W / T$ ratio, meaning a narrow-fronted exploitation of the nodule. In further detail, EG I and EG III cores are proportionally narrower than in the Sharon Plain. On the other hand, EG IV and NEG I present relatively wider surfaces and a greater standard deviation. The Wilcoxon rank-sum test indicates similarly narrow-fronted reduction modality in the EG I and EG III assemblages, as well as for the NH V and Pol 18MII cores. The difference is not significant between EG III and $\mathrm{NH}$ V. EG IV and NEG I are significantly different from all the other assemblages.

\begin{tabular}{lllllllllll}
\hline & N. & MEAN W/T & MEDIAN W/T & W/T SD & EG I & EG III & NEG I & EG IV & POL 18MII & NH V \\
\hline EG I & 115 & 0.56 & 0.53 & 0.24 & - & 0.44 & ${ }^{*} 0.00$ & ${ }^{*} 0.00$ & ${ }^{*} 0.00$ & ${ }^{*} 0.03$ \\
\hline EG III & 34 & 0.55 & 0.44 & 0.25 & 0.44 & - & ${ }^{*} 0.00$ & ${ }^{*} 0.00$ & ${ }^{*} 0.01$ & 0.06 \\
\hline NEG I & 77 & 1.01 & 0.98 & 0.31 & ${ }^{*} 0.00$ & ${ }^{*} 0.00$ & - & ${ }^{*} 0.01$ & ${ }^{*} 0.00$ & ${ }^{*} 0.00$ \\
\hline EG IV & 32 & 0.84 & 0.79 & 0.29 & ${ }^{*} 0.00$ & ${ }^{*} 0.00$ & ${ }^{*} 0.01$ & - & ${ }^{*} 0.01$ & ${ }^{*} 0.00$ \\
\hline Pol 18MII & 60 & 0.68 & 0.64 & 0.25 & ${ }^{*} 0.00$ & ${ }^{*} 0.01$ & ${ }^{*} 0.00$ & ${ }^{*} 0.01$ & - & 0.06 \\
\hline NH V & 151 & 0.61 & 0.58 & 0.20 & ${ }^{*} 0.03$ & 0.06 & ${ }^{*} 0.00$ & ${ }^{*} 0.00$ & 0.06 & - \\
\hline
\end{tabular}

Table 4 Sample sizes, average, median, standard deviation, and p-values of the Wilcoxon rank-sum test (U-test) for the W/T ratio. Asterisks demark significantly different pairs $(\alpha=0.05)$.

\begin{tabular}{|c|c|c|c|c|c|c|c|}
\hline & N. & MEAN T. (MM) & MEDIAN T. (MM) & T. $S D$ (MM) & MEAN W. (MM) & MEDIAN W. (MM) & W. $S D(M M)$ \\
\hline EG I & 115 & 52.2 & 51.2 & 11.07 & 28.2 & 26.0 & 9.3 \\
\hline EG III & 34 & 45.9 & 46.4 & 12.07 & 24.9 & 19.5 & 13.3 \\
\hline NEG I & 77 & 45.0 & 40.9 & 13.44 & 43.5 & 43.7 & 12.5 \\
\hline EG IV & 32 & 44.7 & 41.8 & 15.99 & 34.7 & 36.5 & 9.6 \\
\hline Pol 18MII & 60 & 27.4 & 26.5 & 6.55 & 17.6 & 16.4 & 4.6 \\
\hline $\mathrm{NH} \mathrm{V}$ & 151 & 33.5 & 33.1 & 6.42 & 19.6 & 19.5 & 5.1 \\
\hline
\end{tabular}

Table 5 Sample sizes, average, median, and standard deviation of core thickness (T) and reduction surface width (W). 


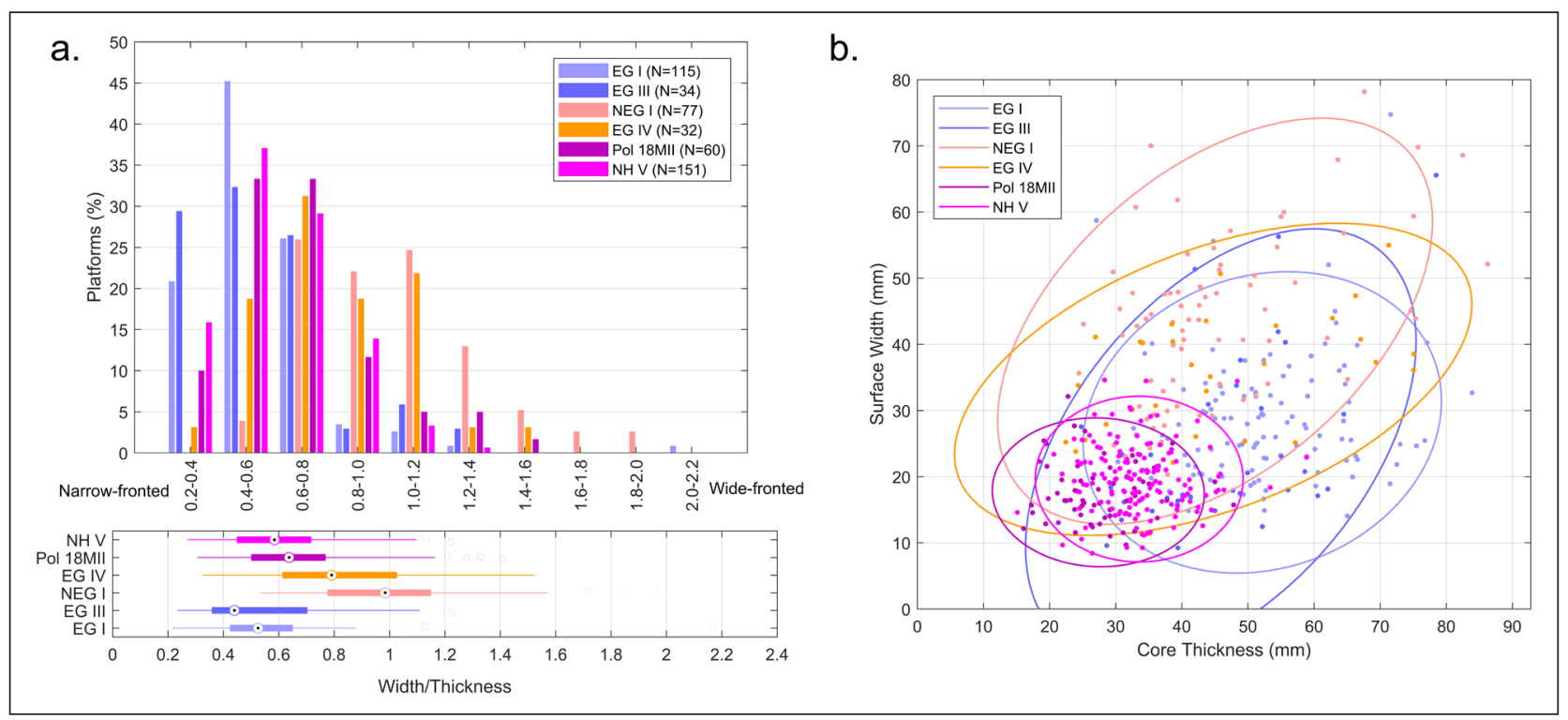

Figure 6 Distribution of striking platforms base on W/T ratio (a) in each assemblage. Scatter-plot of core thickness and surface width with $95 \%$ confidence ellipses (b).

The higher $\mathrm{W} / \mathrm{T}$ ratio in cores from the Sharon Plain can represent a more intense exploitation of the raw material. The relationship between exploitation intensity and the different parameters proposed for its measure is complex. Each parameter may also be affected by technological and economic factors independent of reduction intensity, such as original nodule size and reduction modality (Lombao et al. 2019). In standardized narrow-fronted reduction sequences, the removal of blanks and maintenance of the core convexities results in a progressive reduction of all core dimensions. Yet, core thickness is more affected than length and width, resulting in a progressive increase in the $W / T$ ratio. Our data highlight that the difference in average thickness (27.4-52.2 mm, CV: 0.28; Table 5, Figure 6) between narrow-fronted cores in the Sharon Plain and in the Ein Gev area is more noticeable than the difference in width (17.6-28.2 mm, CV: 0.21). A procedure to estimate the original nodule size and, consequently, the exploitation intensity of abandoned cores was recently proposed by Lombao et al. (2020), based on dimensions of the cores and median thickness of the obtained blanks measured on 3-D models. Although data on Pol 18MII and NH V blank thickness are not currently available, further studies may possibly test the relationship between core dimensions and intensity of exploitation by extending the 3-D measurements to flakes. Additionally, further information can be gained based on lithic raw material surveys in the coastal plain and Ein Gev area.

The high SD in the value of the W/T ratio in NEG I and EG IV assemblages may suggest that the reduction sequence was opportunistically fitted to the shape of the available raw material nodules, rather than focused on shaping and maintaining a standardized proportion. This ad hoc exploitation is compatible with the wide-fronted reduction modality (Marder 2002).

\subsection{BLANK SCARS PROFILE}

The profile of the blank scars is described based on the average angle between subsequent $7 \mathrm{~mm}$ wide segments of its surface and the striking platform (Figure 7; Table 6; (PA). To remove possible profile variability related to the size of the extracted blanks, the study sample was limited to blank scars from 21 to $49 \mathrm{~mm}$ long (i.e., including 3 to 7 segments) and less than $15 \mathrm{~mm}$ wide (see above). After the removal of outliers (more than three scaled median absolute deviations away from the median), in each assemblage only the bands for which more than 30 scars returned a valid angle measurement were included in the analysis.

\begin{tabular}{lllllllllll}
\hline & N. & $\begin{array}{l}\text { MEAN ANGLE } \\
\text { (DEG.) }\end{array}$ & $\begin{array}{l}\text { MEDIAN } \\
\text { ANGLE (DEG.) }\end{array}$ & $\begin{array}{l}\text { ANGLE } \\
\text { SD (DEG.) }\end{array}$ & EG I & EG III & NEG I & EG IV & POL 18MII & NH V \\
\hline \multicolumn{2}{l}{ Distance: $\mathbf{0 - 7 ~ m m ~}$} & & & & & & & & & \\
\hline EG I & 299 & 81.3 & 81.3 & 12.1 & - & 0.28 & 0.67 & 0.62 & ${ }^{*} 0.02$ & ${ }^{*} 0.00$ \\
\hline EG III & 67 & 83.1 & 83.6 & 9.9 & 0.28 & - & 0.52 & 0.22 & ${ }^{*} 0.01$ & ${ }^{*} 0.00$ \\
\hline NEG I & 161 & 82.2 & 81.7 & 12.5 & 0.67 & 0.52 & - & 0.42 & ${ }^{*} 0.01$ & ${ }^{*} 0.00$ \\
\hline
\end{tabular}




\begin{tabular}{|c|c|c|c|c|c|c|c|c|c|c|}
\hline & N. & $\begin{array}{l}\text { MEAN ANGLE } \\
\text { (DEG.) }\end{array}$ & $\begin{array}{l}\text { MEDIAN } \\
\text { ANGLE (DEG.) }\end{array}$ & $\begin{array}{l}\text { ANGLE } \\
S D(D E G .)\end{array}$ & EG I & EG III & NEG I & EG IV & POL 18MII & NH V \\
\hline EG IV & 65 & 80.8 & 80.1 & 12.6 & 0.62 & 0.22 & 0.42 & - & 0.22 & 0.07 \\
\hline Pol 18MII & 128 & 78.2 & 77.3 & 16.2 & ${ }^{*} 0.02$ & ${ }^{*} 0.01$ & ${ }^{*} 0.01$ & 0.22 & - & 0.58 \\
\hline NHV & 31 & 77.2 & 77.0 & 15.4 & ${ }^{*} 0.00$ & ${ }^{*} 0.00$ & ${ }^{*} 0.00$ & 0.07 & 0.58 & - \\
\hline \multicolumn{11}{|c|}{ Distance: 7-14 mm } \\
\hline EG I & 301 & 76.1 & 75.7 & 13.8 & - & 0.21 & ${ }^{*} 0.00$ & ${ }^{\star} 0.01$ & ${ }^{*} 0.00$ & ${ }^{*} 0.00$ \\
\hline EG III & 66 & 78.2 & 76.8 & 9.9 & 0.21 & - & ${ }^{*} 0.00$ & 0.26 & ${ }^{*} 0.00$ & ${ }^{*} 0.00$ \\
\hline NEG I & 164 & 83.2 & 82.7 & 11.9 & ${ }^{*} 0.00$ & ${ }^{*} 0.00$ & - & 0.19 & ${ }^{*} 0.00$ & ${ }^{*} 0.00$ \\
\hline EG IV & 65 & 80.4 & 81.5 & 11.4 & ${ }^{*} 0.01$ & 0.26 & 0.19 & - & ${ }^{*} 0.00$ & ${ }^{*} 0.00$ \\
\hline Pol 18MII & 125 & 67.7 & 65.9 & 16.5 & ${ }^{*} 0.00$ & ${ }^{*} 0.00$ & ${ }^{*} 0.00$ & ${ }^{*} 0.00$ & - & 0.89 \\
\hline $\mathrm{NH} \mathrm{V}$ & 311 & 67.0 & 66.8 & 16.0 & ${ }^{*} 0.00$ & ${ }^{*} 0.00$ & ${ }^{*} 0.00$ & ${ }^{*} 0.00$ & 0.89 & - \\
\hline \multicolumn{11}{|c|}{ Distance: 14-21 mm } \\
\hline EG I & 292 & 72.8 & 71.9 & 15.2 & - & 0.29 & ${ }^{*} 0.00$ & ${ }^{*} 0.00$ & $* 0.00$ & ${ }^{*} 0.00$ \\
\hline EG III & 65 & 75.1 & 71.2 & 13.5 & 0.29 & - & ${ }^{*} 0.00$ & ${ }^{*} 0.01$ & ${ }^{*} 0.00$ & ${ }^{*} 0.00$ \\
\hline NEG I & 162 & 82.1 & 81.0 & 11.6 & ${ }^{\star} 0.00$ & ${ }^{*} 0.00$ & - & 0.69 & ${ }^{*} 0.00$ & ${ }^{*} 0.00$ \\
\hline EG IV & 63 & 82.0 & 81.8 & 14.9 & ${ }^{\star} 0.00$ & ${ }^{*} 0.01$ & 0.69 & - & ${ }^{*} 0.00$ & ${ }^{*} 0.00$ \\
\hline Pol 18MII & 123 & 63.0 & 59.5 & 18.5 & ${ }^{*} 0.00$ & ${ }^{*} 0.00$ & ${ }^{*} 0.00$ & ${ }^{*} 0.00$ & - & ${ }^{*} 0.05$ \\
\hline $\mathrm{NHV}$ & 311 & 67.5 & 64.3 & 20.6 & ${ }^{*} 0.00$ & ${ }^{*} 0.00$ & ${ }^{*} 0.00$ & ${ }^{\star} 0.00$ & ${ }^{*} 0.05$ & - \\
\hline \multicolumn{11}{|c|}{ Distance: $21-28 \mathrm{~mm}$} \\
\hline EG I & 224 & 67.3 & 66.5 & 15.0 & - & 0.75 & ${ }^{*} 0.00$ & ${ }^{\star} 0.00$ & ${ }^{*} 0.00$ & ${ }^{*} 0.01$ \\
\hline EG III & 51 & 68.4 & 65.0 & 14.2 & 0.75 & - & ${ }^{*} 0.00$ & ${ }^{\star} 0.00$ & ${ }^{*} 0.00$ & ${ }^{*} 0.05$ \\
\hline NEG I & 133 & 79.6 & 79.0 & 15.4 & ${ }^{*} 0.00$ & ${ }^{*} 0.00$ & - & 0.96 & ${ }^{*} 0.00$ & ${ }^{*} 0.00$ \\
\hline EG IV & 47 & 80.7 & 78.2 & 18.4 & ${ }^{*} 0.00$ & ${ }^{*} 0.00$ & 0.96 & - & ${ }^{*} 0.00$ & ${ }^{*} 0.00$ \\
\hline Pol 18MII & 75 & 52.9 & 49.9 & 21.6 & ${ }^{*} 0.00$ & ${ }^{*} 0.00$ & ${ }^{*} 0.00$ & ${ }^{\star} 0.00$ & - & ${ }^{*} 0.00$ \\
\hline $\mathrm{NHV}$ & 206 & 63.7 & 62.3 & 20.7 & ${ }^{*} 0.01$ & ${ }^{*} 0.05$ & ${ }^{*} 0.00$ & ${ }^{\star} 0.00$ & ${ }^{*} 0.00$ & - \\
\hline \multicolumn{11}{|c|}{ Distance: $28-35 \mathrm{~mm}$} \\
\hline EG I & 150 & 61.2 & 60.2 & 16.7 & - & - & ${ }^{*} 0.00$ & - & - & 0.23 \\
\hline EG III & 28 & - & - & - & - & - & - & - & - & - \\
\hline NEG I & 99 & 76.7 & 75.3 & 17.4 & ${ }^{*} 0.00$ & - & - & - & - & ${ }^{*} 0.00$ \\
\hline EG IV & 26 & - & - & - & - & - & - & - & - & - \\
\hline Pol 18MII & 17 & - & - & - & - & - & - & - & - & - \\
\hline $\mathrm{NH}$ V & 129 & 61.4 & 56.1 & 28.1 & 0.23 & - & ${ }^{*} 0.00$ & - & - & - \\
\hline \multicolumn{11}{|c|}{ Distance: $35-42 \mathrm{~mm}$} \\
\hline EG I & 73 & 55.1 & 55.9 & 18.4 & - & - & ${ }^{*} 0.00$ & - & - & 0.29 \\
\hline EG III & 12 & - & - & - & - & - & - & - & - & - \\
\hline NEG I & 57 & 69.9 & 68.8 & 18.3 & *0.00 & - & - & - & - & ${ }^{*} 0.00$ \\
\hline EG IV & 18 & - & - & - & - & - & - & - & - & - \\
\hline Pol 18MII & 0 & - & - & - & - & - & - & - & - & - \\
\hline NH V & 52 & 53.9 & 51.1 & 25.2 & 0.29 & - & ${ }^{*} 0.00$ & - & - & - \\
\hline
\end{tabular}

Table 6 Sample sizes (without outliers), average, median, standard deviation, and p-values of the Wilcoxon rank-sum test (U-test) for CPA Asterisks demark significantly different pairs $(\alpha=0.05)$. 


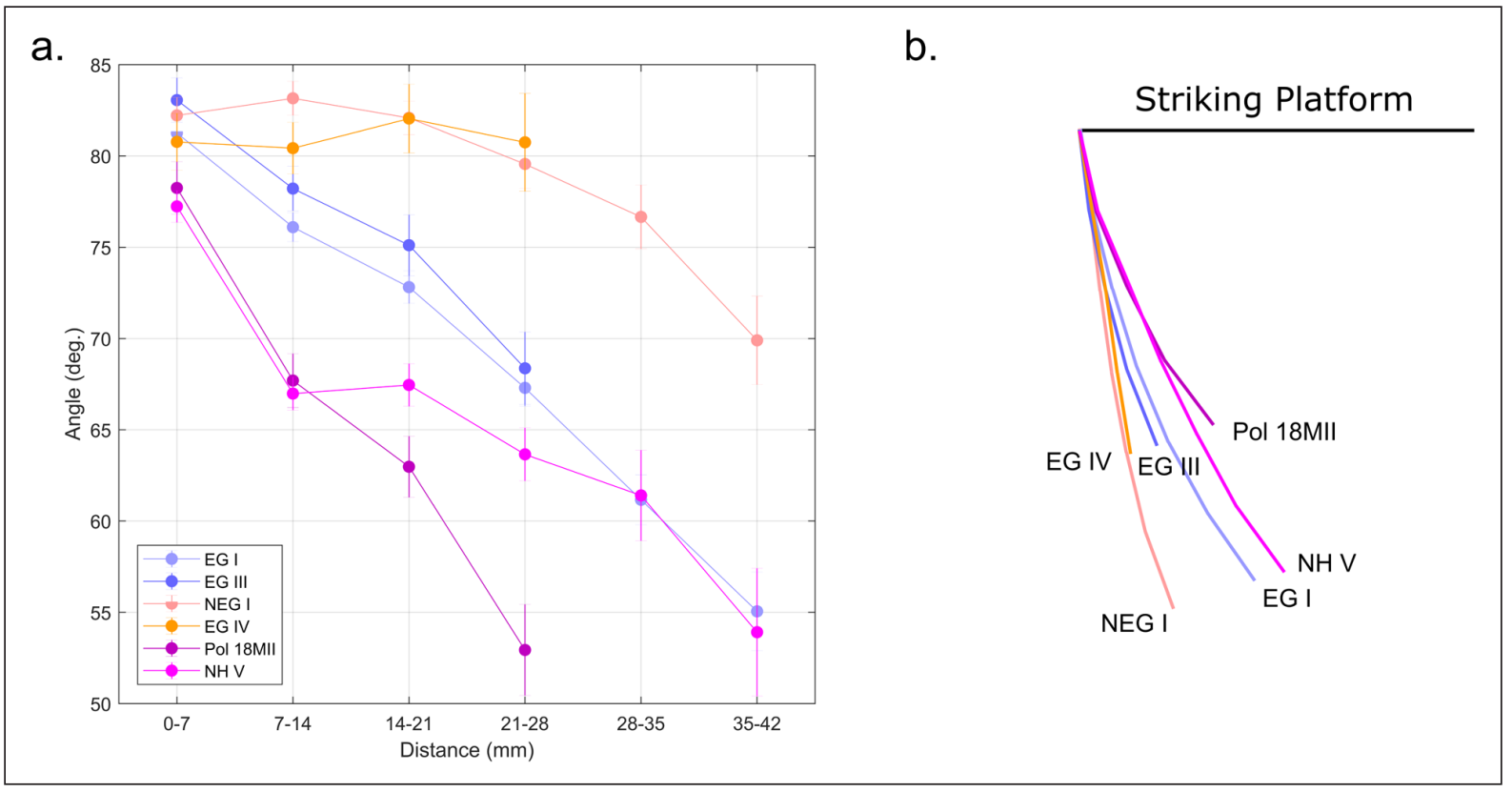

Figure 7 CPA average and SD values (a), and schematic average blank profile (b) of each assemblage.

In all the assemblages the average angle between the striking platform and the first $7 \mathrm{~mm}$ band is around 80 degrees. Based on the subsequent average blank scar profile, it is possible to sort the assemblages into three groups:

- Blank scars of NEG I and EG IV maintain an angle of ca. 80 degrees along their whole proximal profile, until $28 \mathrm{~mm}$ from the platform, when the angle value starts to decrease. This translates to an initially straight profile that becomes convex distally.

- In the EG I and EG III assemblages, the average angle with the striking platform decreases progressively along the entire length of the blank scars, reaching a value of ca. 60 degrees at $35 \mathrm{~mm}$ from the platform. Their blank scars thus have a homogenous convexity all along their length.

- The Pol 18MII and NH V cores often possess a sharp drop along the proximal portion of the profile, reaching an angle of ca. 65 degrees at $14 \mathrm{~mm}$ from the platform. Distally, the two assemblages present slightly different average profiles. In Pol 18MII, the value decreases continuously along the reduction surface, resulting in a homogenously convex profile, with a sharper curve than the ones seen in EG I-III. In $\mathrm{NH} \mathrm{V}$, the angle value decreases more gently, resulting in an almost straight profile, maintaining a smaller angle than in the Ein Gev area.

These observations are supported by the results of the Wilcoxon rank-sum test (Table 6), that show no significant difference between EG I and EG III, and between NEG I and EG IV in the three bands from 7 to $28 \mathrm{~mm}$. In the last bands, Pol 18MII presents significatively narrower angles than $\mathrm{NH} \mathrm{V.}$
Previous theoretical and experimental works (Clarkson \& Hiscock 2011; Dibble 1997; Dibble \& Rezek 2009; Lin et al. 2013; Muller \& Clarkson 2014; Rezek et al. 2011; Speth 1972) demonstrated the role of platform angle in determining the length of the extracted blanks. Focusing only on blank scars with lengths between 21 and $49 \mathrm{~mm}$ allows to exclude variability in blank length as a possible cause of the observed variability in their longitudinal profile. A possible technological solution for extracting equally long blanks from a reduction surface with a smaller angle is increasing the distance between the platform edge and the striking point, thereby increasing the thickness of the blank. Thickness data available for the Ein Gev blanks (Belfer-Cohen et al. 2004; Valletta \& Grosman 2021) suggest that this is not the case. Although in EG I and EG III the CPA decreases more steeply with the distance from the striking platform, blanks with lengths between 21-49 $\mathrm{mm}$ in these assemblages are, on average, thinner (2.7 and $2.8 \mathrm{~mm}$ respectively) than in EG IV $(3.0 \mathrm{~mm}$ ) and NEG I $(3.0 \mathrm{~mm}$ - length range: 16-38 mm).

Replicative experiments (Clarkson \& Hiscock 2011; Muller \& Clarkson 2014, 2016) suggest that platform type may have a role in controlling the size and shape of the extracted blanks. Additionally, although to date no controlled experiment was conducted to test this hypothesis, physical properties of the raw material are expected to also affect the fracture process during percussion knapping (Speth 1972). Yet, in all the studied assemblages, the dominant platform type is flat and the exploited raw material is fine-grained flint (Shimelmitz 2002; Valletta \& Grosman 2021; author personal observation for Pol 18MII - FV).

Finally, the size and shape of the extracted flakes can be controlled by adjusting the knapping technique, 
or the modality in which force is delivered to the core (Tixier 1967: 807), including angle of blow, strike location and hammer hardness (Magnani et al. 2014). Holding constant the length and thickness of the target blanks, the quality of the raw material, the type of platform, and the difference in average platform angle between the assemblages may point to variability in these aspects of the knapping technique.

\subsection{PLATFORM EDGE SMOOTHNESS}

The smoothness of blank scar platforms is measured based on the average curvature (AC) of the portion of ridge shared by each blank scar and its relative striking platform (Shared Ridge - SR). This measure reflects the position of the single vertices of the $3-D$ mesh along the platform edge. The 3-D mesh is comprised of triangles, making this platform edge naturally jagged at very high resolution. Therefore, a maximum resolution threshold was set, including only the ridges with average distances between the vertices greater than $0.2 \mathrm{~mm}$. Additionally, to remove possible variability related to the size of the extracted blanks, only platforms narrower than 15 $\mathrm{mm}$ were included in the sample (see above). These restrictions (resolution and width) resulted in narrowing of the sample sizes. Consequently, the assemblage from Pol 18MII (only 15 blank platforms) was excluded.

In this feature, all assemblages from Ein Gev have mean values lower than $\mathrm{NH} \mathrm{V}$ with lower standard deviation (Figure 8; Table 7). Results of the Wilcoxon ranksum test highlight that the difference in smoothness

\begin{tabular}{llllllllll}
\hline & N & MEAN AC $(1 / \mathrm{mm})$ & MEDIAN AC $(1 / \mathrm{mm})$ & AC SD $(1 / \mathrm{mm})$ & EG I & EG III & NEG I & EG IV & NH V \\
\hline EG I & 241 & 0.7 & 0.7 & 0.2 & - & ${ }^{*} 0.00$ & 0.19 & ${ }^{*} 0.01$ & ${ }^{*} 0.00$ \\
\hline EG III & 48 & 0.8 & 0.7 & 0.3 & ${ }^{*} 0.00$ & - & ${ }^{*} 0.03$ & 0.53 & ${ }^{*} 0.00$ \\
\hline NEG I & 155 & 0.7 & 0.7 & 0.2 & 0.19 & ${ }^{*} 0.03$ & - & 0.15 & ${ }^{*} 0.00$ \\
\hline EG IV & 65 & 0.8 & 0.8 & 0.2 & ${ }^{*} 0.01$ & 0.53 & 0.15 & - & ${ }^{*} 0.00$ \\
\hline NH V & 157 & 1.2 & 1.1 & 0.4 & ${ }^{*} 0.00$ & ${ }^{*} 0.00$ & ${ }^{*} 0.00$ & ${ }^{*} 0.00$ & - \\
\hline
\end{tabular}

Table 7 Sample sizes, average, median, standard deviation, and p-values of the Wilcoxon rank-sum test (U-test) for AC. Asterisks demark significantly different pairs $(\alpha=0.05)$.

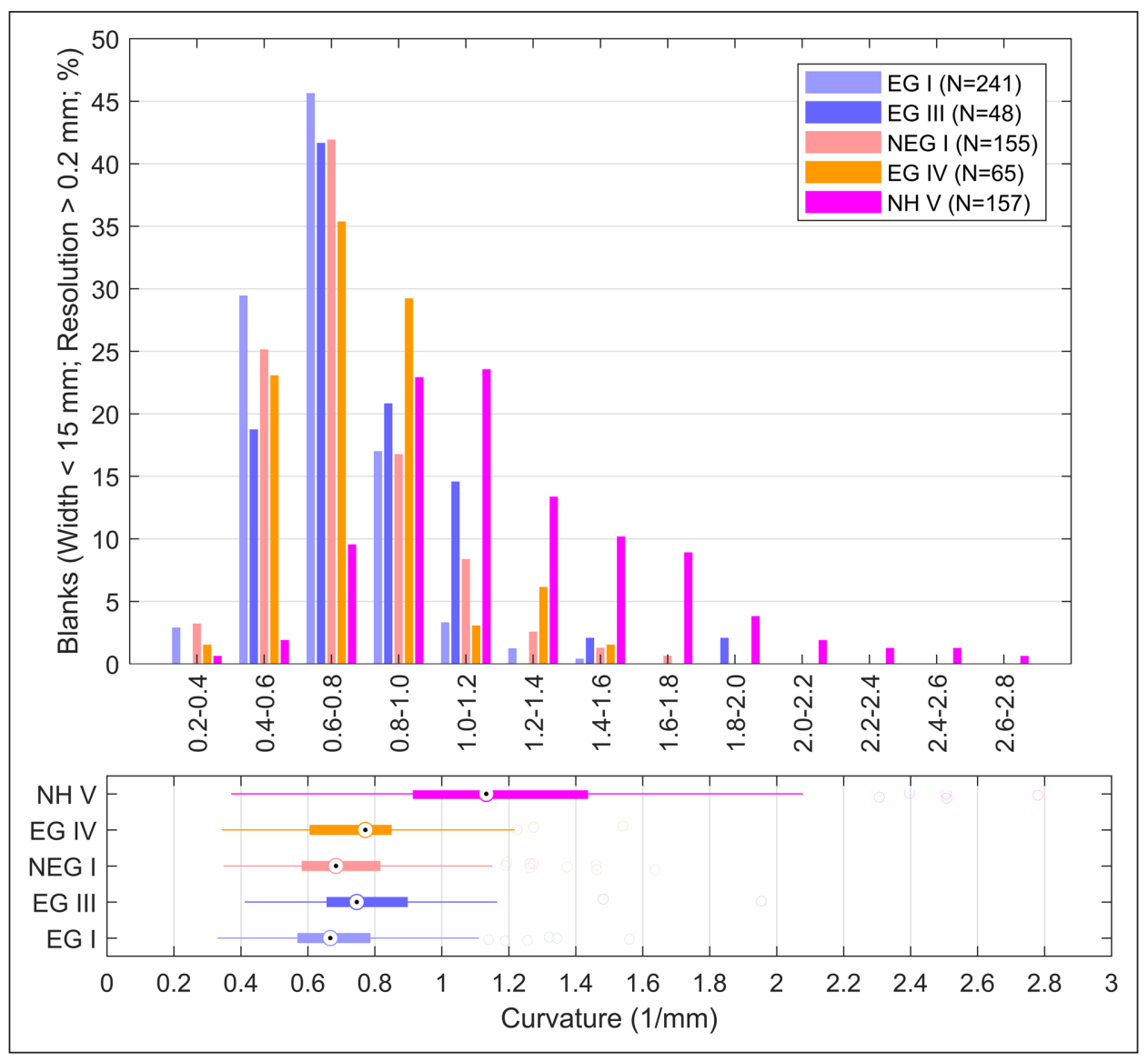

Figure 8 Distribution of blanks based on AC in each assemblage. 
observed between $\mathrm{NH} \mathrm{V}$ and all the other assemblages is significant ( Table 7).

In soft-hammer, direct percussion techniques (including organic and soft-stone percussion), the striking platform is hit close to its edge, allowing the removal of thin, elongated blanks. Abrading the platform edge before the blow preventively removes the more fragile portions of the edge, that may otherwise be shattered during percussion, hindering successful blank removal (Pelegrin 2000). Platform edge abrasion may also occur via secondary use of the core as a tool (e.g., a scraper) or by post-depositional processes like trampling (Marwick 2008; Shea \& Klenck 1993). Abrasion results in a local increase of the platform angle. Excessively intense platform edge abrasion may, thus, result in an unsuitable angle for extracting thin blanks (Pelegrin 2000), yet it may not affect the functionality of the artifact edge as a tool. Technological abrasion is, therefore, expected to be less intense than use-wear.

A visual inspection of cores was conducted to test the relationship between $\mathrm{AC}$ and the nature of platform abrasion caused by technological, functional, or postdepositional processes. Blank scars partially obscuring the abrasion suggest that the abrasion occurred before the extraction of blanks, thus likely reflecting a technological choice of the knapper during the reduction sequence (Sheets 1973). On the other hand, when abrasion covers the edge of the striking platform uninterrupted, it likely occurred after the blank production, possibly due to secondary use of the core or due to post-depositional processes. Finally, in the case of secondary use, use-wear is expected to be localized only on the active edges of the artifact, while post-depositional abrasion is expected to be visible on all the edges with a similar angle.

- In NEG I and EG IV, abrasion is rarely encountered and, when present, is interrupted by blank scars. Based on these observations, it likely reflects the technological choice to abrade the edge of the striking platform to better control the breakage of the flint during soft-hammer percussion (stone or organic; Pelegrin 2000).

- Most of the EG I and EG III cores possess abraded striking platforms. Both fresh and abraded edges are visible on the same core, excluding the postdepositional explanation. When present, platform abrasion is either continuous along the whole platform edge or interrupted by blank scars. The relatively low AC measured in these assemblages is compatible with light, technological platform abrasion. Blank scars with fresh platforms are often hinged or exposed problems in the raw material (e.g., inclusions or fractures). It thus appears that striking platforms were systematically abraded after successful blank removals.
- In NH V, the edges of the striking platforms frequently present an invasive abrasion (high AC), not interrupted by blank removals, sometimes visible on both the reduction surface and the platform. The presence, on the same core, of both fresh and abraded edges and the directionality of the abrasion (visible only on one of the edge surfaces) rules out the post-depositional explanation. In some cases, abrasion is absent on the striking platform edge, but it can be seen on other core edges with similar angles, suggesting secondary use of the cores as tools. Additionally, the abrasion intensity is often so high as to compromise the platform edge for subsequent bladelet removals (i.e., a suitable platform angle can be found only by striking at a relatively large distance from the edge), further suggesting that, in this assemblage, cores were systematically re-used as tools.

Combining AC data with the visual inspection of cores, it appears that the more intense abrasion encountered in $\mathrm{NH} \mathrm{V}$ can be related with secondary use of cores as heavy scrapers, while the lower values in the other assemblages likely reflects technological abrasion during the blank extraction process.

\section{DISCUSSION}

A series of novel tools, based on digital 3-D models, are introduced for measuring core features reflecting technological traits of the reduction sequence with different degree of visibility and malleability (Table 8). In search of technological traits that could be harnessed in tracking specific local communities, we defined three parameters based on the automatic segmentation of scars on the core surface (Richardson et al. 2013). Specifically, we measured the ratio between reduction surface width and core thickness (W/T), the average angle between the striking platform and subsequent bands of the blank scars at increasing distance (CPA), and the average curvature of the ridge between the striking platform and the blank scars (AC). The first two parameters can be related with knapping method and technique respectively (sensu Tixier 1967: 807). They reflect technological traits of the tool manufacturing process and allow us to track cultural affinities among the lithic assemblages. On the other hand, our analysis suggested that $A C$ could be related with the secondary use of cores as scraping tools.

W/T ratio reflects the knapping method, allowing us to objectively rank cores from narrow- to wide-fronted. The relatively low ratios of Kebaran and Geometric Kebaran core assemblages in the Ein Gev area (EG I and EG III) and in the Sharon Plain (Pol 18MII and NH V) indicate that their manufacturing traditions were characterized by the 


\begin{tabular}{|c|c|c|c|c|c|c|}
\hline & EG I & EG III & NEG I & EG IV & POL 18MII & NH V \\
\hline $\begin{array}{l}\text { Reduction modality } \\
\text { (W/T) }\end{array}$ & $\begin{array}{l}\text { Narrow-fronted } \\
(0.56)\end{array}$ & $\begin{array}{l}\text { Narrow-fronted } \\
(0.55)\end{array}$ & $\begin{array}{l}\text { Wide-fronted } \\
(1.01)\end{array}$ & $\begin{array}{l}\text { Wide-fronted } \\
(0.84)\end{array}$ & $\begin{array}{l}\text { Narrow-fronted } \\
(0.68)\end{array}$ & $\begin{array}{l}\text { Narrow-fronted } \\
(0.61)\end{array}$ \\
\hline $\begin{array}{l}\text { Blank profile (CPA: } \\
0-7 ; 21-28 \mathrm{~mm} \text {; deg.) }\end{array}$ & $\begin{array}{l}\text { Convex } \\
(81.3-67.3)\end{array}$ & $\begin{array}{l}\text { Convex } \\
(83.1-68.4)\end{array}$ & $\begin{array}{l}\text { Straight } \\
(82.2-79.6)\end{array}$ & $\begin{array}{l}\text { Straight } \\
(80.8-80.7)\end{array}$ & $\begin{array}{l}\text { Convex, Narrow } \\
\text { angle } \\
(78.2-52.9)\end{array}$ & $\begin{array}{l}\text { Straight, Narrow } \\
\text { angle } \\
(77.2-63.7)\end{array}$ \\
\hline $\begin{array}{l}\text { Platform abrasion } \\
\text { (AC; } 1 / \mathrm{mm} \text { ) }\end{array}$ & $\begin{array}{l}\text { Technological } \\
(0.7)\end{array}$ & $\begin{array}{l}\text { Technological } \\
(0.8)\end{array}$ & $\begin{array}{l}\text { Technological } \\
(0.7)\end{array}$ & $\begin{array}{l}\text { Technological } \\
(0.8)\end{array}$ & - & $\begin{array}{l}\text { Use-wear } \\
(1.2)\end{array}$ \\
\hline
\end{tabular}

Table 8 Summary of the quantitative traits measured in each of the lithic assemblages.

narrow-fronted reduction method. On the other hand, the Atlitian and Nizzanan of the Ein Gev area (NEG I and EG IV) were characterized by a less standardized widefronted reduction method.

Like other traits of the lithic manufacturing process, the knapping method is barely visible during inter-group interactions and hardly integrated into a pre-existing technological framework (technologically rigid), hindering horizontal transmission among groups (Gosselain 2000; Premo \& Tostevin 2016). Yet, on an intra-group level, the outcome of methodological choices (e.g., narrow- or wide-fronted cores) remains visible with the naked eye after the knapping action. Additionally, cores may have been re-used as lithic tools, remaining in circulation for a relatively long time and further increasing their visibility within the user community. Traits of knapping methods may have, thus, been subject to social evaluation for authenticity, enhancing conservativism (Hiscock 2014). Therefore, the $W / T$ ratio can be employed to link the manufacturing traditions represented by the six lithic assemblages studied here to geographically and chronologically widespread 'lineages' of historically related human groups, that maintained similar reduction modalities over time.

Continuity in the use of a non-standardized, widefronted method in the Atlitian and Nizzanan of the Ein Gev area (NEG I and EG IV) suggests that these occupations were linked to the same cultural lineage. On the other hand, a different cultural lineage is suggested by continuity in the use of the narrow-fronted method in the Kebaran and Geometric Kebaran of the Ein Gev area (EG I and EG III) and the Sharon Plain (Pol 18MII and $\mathrm{NH}$ V). Variability in the W/T ratio within this cluster of sites reflects their geographical distribution, with greater similarity between EG I and EG III than between these and the Sharon sites. This pattern is possibly related with the abundance, quality, and original shape of the available lithic raw material, rather than with geographical patterns in the manufacturing traditions (Brantingham 2003, 2006; Pop 2016). Further investigation, possibly including raw material surveys in the two areas, may clarify the origin of the variability in this technological trait.

Blank scar profile (CPA) can be linked to variables in the force application during blank extraction (Magnani et al. 2014), that, in turn, reflect traits of the knapping technique (sensu Tixier 1967: 807). Variability in CPA allows us to sort the core assemblages into three clusters with sharp chronological and geographic boundaries: the Atlitian and Nizzanan occupations of the Ein Gev area (NEG I and EG IV), the Late Kebaran and Geometric Kebaran occupations of the same area (EG I and EG III), and the Early and Late Kebaran occupations of the Sharon Plain (NH V).

Unlike methodological ones (e.g., the exploitation of narrow- or wide-fronted cores), traits of knapping technique are likely visible only during the knapping process (their material outcome is barely visible with the naked eye) and within the manufacturing community. The vertical transmission of fine nuances of the manufacturing technique therefore requires an uninterrupted chain of teachers and learners (Hiscock 2014). Core features related to technical traits can consequently be used to track specific continuous learning communities.

The intensity of platform abrasion, measured based on AC, reflects patterns in secondary use of cores as tools. The use of carinated core-scrapers does not involve any technological solution different from 'formal' end-scrapers, and is thus, a highly malleable technological behavior. Rather than reflecting the vertical transmission of technological traits (Gosselain 2000), this feature can be related with the performance within the site of activities requiring thick and robust scraping devices. Our data highlight a more intense secondary use of cores as scrapers in $\mathrm{NH} \mathrm{V} \mathrm{compared}$ to sites in the Ein Gev area, that may in turn, represent a technological solution adopted to possibly exploit the different natural resources available in the coastal plain area. Versatile artifacts that can be used for different purposes (Nelson 1991) are encountered in many different archaeological contexts (e.g.; Centi et al. 2019; Claud et al. 2010; Cuartero et al. 2015; Hiscock 2009, 2015; Jacquier \& Naudinot 2015; Rios-Garaizar, Eixea \& Villaverde 2015; Shimelmitz 2015; Vaquero et al. 2012, 2015; Wojtczak 2015), together with other forms of recycling and opportunistic behavior (e.g.; Agam, Marder \& Barkai 2015; Assaf et al. 2015; Barsky et al. 2015; Lemorini et al. 2015; Parush et al. 2015). Further analysis may support the technological or economic nature of the variability. 


\subsection{MANUFACTURING TRADITIONS}

Technological traits of the local core assemblages reflected by W/T an CPA suggest two markedly separated manufacturing traditions in the Ein Gev area. One is represented by NEG I and EG IV, characterized by widefronted reduction modality and straight reduction surfaces, the other by EG I and EG III, characterized by narrow-fronted modality and carinated surfaces. The available chronological data on the Kebaran (21,00018,000 cal BP - Goring-Morris \& Belfer-Cohen 2017) and Nizzanan (20,000-18,500 cal BP) cultural entities provides us with a general chronological framework. However, we are missing absolute dates to establish the local Ein Gev sequence. Yet, the substantial difference between the two assemblages in traits of the reduction modality and technique, in the typological composition of the tool assemblages, and in other stylistic traits such as the use (or lack thereof) of MbT (Henry 1974) suggest that they may represent occupations of the area by populations with different manufacturing traditions. One tradition (EG IV) maintains the technological traits (wide-fronted cores with straight reduction surface profile) of the local UP tradition (NEG I), introducing or adopting novel typological solutions (Nizzanan microliths, use of MbT). The other (EG I) possibly represents a group of newcomers, characterized by a completely new set of technological (narrow-fronted, carinated cores) and typological traits (Kebaran microliths, lack of $\mathrm{MbT}$ ). The marked continuity in reduction modality and technique between EG I and EG III suggests that the EG I population may have continued to occupy the area in later phases of the pre-Natufian EP, adopting the typological traits of the Geometric Kebaran cultural entity.

The quantitative, 3-D based, analysis of traits of the reduction sequence in the Ein Gev area supports the result of our previous traditional technological analysis (Valletta \& Grosman 2021), highlighting long-term continuity between different occupation phases. The local Atlitian (NEG I) and Nizzanan (EG IV) reduction sequences were characterized by the exploitation of wide-fronted cores after no or minimal shaping for the extraction of bladelets with wide, flat platforms. On the other hand, the Kebaran (EG I) and Geometric Kebaran (EG III) reduction sequences presented systematic and intensive shaping of the available nodules, producing highly standardized, narrow, curved bladelets. Surface convexities on these narrow-fronted cores were maintained through a fixed set of operations, evidenced by standardized core trimming elements. The quantitative nature of the 3-D based data allows us to assess the degree of variability among the assemblages. Additionally, extending the analysis to the Sharon Plain highlighted local continuity in technological traits between different occupation phases, suggesting the existence of a local manufacturing tradition, partially different from the ones observed at Ein Gev. Finally, including in the analysis technological features with different visibility and malleability allows us to track possible cultural affinities among the lithic assemblages on different hierarchical levels (Gosselain 2000; Premo \& Tostevin 2016), increasing the resolution of traditional qualitative analyses.

Geographical and chronological continuity in traits of the reduction sequence, based on the $W / T$ ratio, indicates that different local learning communities, representing different cultural entities in different geographical areas, might have been historically related, sharing a technological background possibly inherited through a common ancestry (Figure 9). For example, the carefully shaped and maintained narrow-fronted cores typical of the Kebaran and Geometric Kebaran in Ein Gev and in

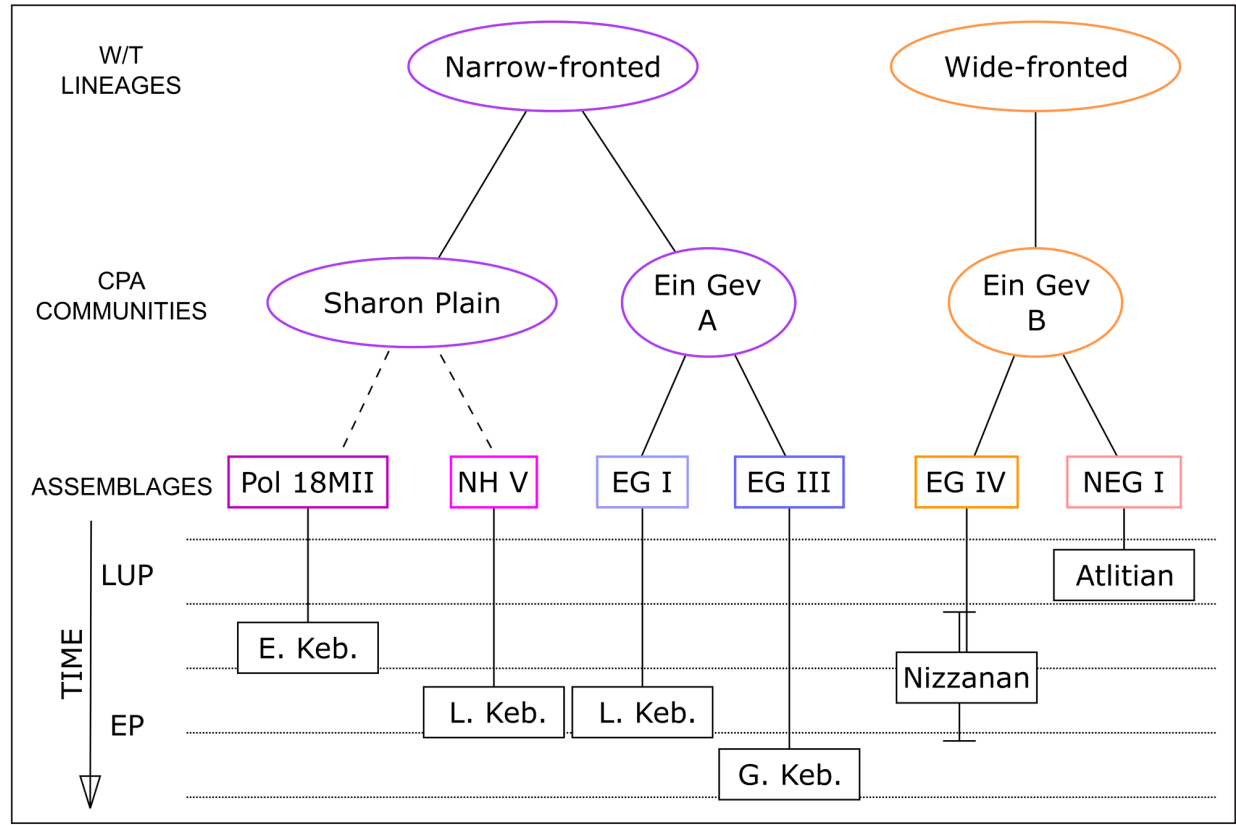

Figure 9 Graph showing the historical relations among the lithic assemblages on different hierarchical levels, their attribution to different typologically defined cultural entities, and their proposed chronological sequence. 
the Sharon Plain appear earlier, in the UP Early Ahmarian cultural entity (Bretzke \& Conard 2012; Davidzon \& Goring-Morris 2003; Goring-Morris et al. 1998; GoringMorris \& Davidzon 2006; Hussain 2015). Ahmarian cores were carefully prepared to extract standardized, regularly shaped, elongated blanks that could have been easily modified into El-Wad points through marginal retouch. Conversely, the use of invasive abrupt retouch to shape Kebaran and Geometric Kebaran microliths loosened the bound between the blank shape and the final tool (BelferCohen \& Goring-Morris 2002), yet a highly standardized narrow-fronted reduction method was maintained in the Kebaran and Geometric Kebaran assemblages included in the present study. The survival of the Ahmarian reduction method empirically confirms the expectation that this is a highly conservative technological trait.

Within geographically and chronologically widespread cultural lineages, technological traits were vertically transmitted among generations of different learning communities (Figure 9). The lower intra-group visibility of the knapping technique (tracked using CPA) may have resulted in a less stringent evaluation for authenticity than for method (Hiscock 2014), allowing the development of particular traits by specific communities. The attribution of lithic assemblages to learning communities defined on knapping technique do not correspond to their attribution to cultural entities based on typological traits (Figure 9). Compared to technological traits, typological ones are malleable and highly visible. They are, therefore, more likely to be transmitted between horizontally interconnected communities (Gosselain 2000; Premo $\&$ Tostevin 2016). The presence in a lithic assemblage of a specific set of standardized tool types may reflect belonging to a widespread horizontal network of coeval communities, not necessarily historically related. Local learning communities within typologically homogenous EP cultural entities were previously suggested based on variability in microlith shape and use (Macdonald 2013) and in the manufacturing process (Marder 2002). The present study highlighted the possible chronological depth of these manufacturing traditions, that may have locally outlasted typologically defined cultural entities, suggesting a long-term bond between a community and a specific territory. Specifically, continuity in traits of the knapping technique between NEG I (Atlitian) and EG IV (Nizzanan) suggests an early development of territorial behavior, at least from the LUP.

\section{CONCLUSIONS}

The assemblages can be differently grouped based on each of the three measured features. Three separate learning communities can be defined based on traits of the knapping technique, reflected by blank scar profile
(CPA): EG I-EG III, NEG I-EG IV, and Pol 18MII-NH V. In turn, these communities can be grouped into two widespread cultural lineages, respectively characterized by wide- and narrow-fronted reduction modalities. The more intense platform abrasion distinguishes $\mathrm{NH} \mathrm{V}$ from the sites in the Ein Gev area, possibly reflecting the more frequent use of cores as scraping tools to exploit the different resources offered by the coastal plain environment. Only one of the introduced parameters can be related to learning communities, the main object of the present archaeological investigation. Further analysis, tracking prehistoric communities based on a wider set of archaeological features, may support or falsify our results.

We introduced a novel set of digital tools for measuring features of lithic artifacts that reflect traits of the lithic reduction sequence with different technological malleability and visibility. The automatic segmentation of the 3D models in scars (Richardson et al. 2013) increases the objectivity of the obtained measurements, limiting the subjective interpretation of the analyst to the merging of over-segmented scars and the selection of technologically relevant blank-scars and striking platforms.

Combining the results of the present analysis with analogous quantitative data from other coeval lithic assemblages from different sub-regions of the Levant may highlight different patterns in territoriality, possibly related to different environmental constraints (Byrd, Garrard \& Brandy 2016). This will shed further light on the circulation of people and ideas in the terminal stages of the Palaeolithic.

Additionally, the increased accuracy, repeatability, and objectivity in the measurement of local features introduced by this set of tools may be harnessed for other archaeological questions related to the manufacturing and use of lithic artifacts. For example, the intensity of the platform abrasion, measured based on AC, may reflect the use of cores as carinated scrapers. The quantitative nature of this parameter may be applied to objectively rank artifacts on a scale from core to tool (Belfer-Cohen \& Grosman 2007), allowing the classification of ambiguous items and, eventually, increasing the amount of information on lithic artifact manufacturing and use.

\section{ADDITIONAL FILE}

The additional file for this article can be found as follows:

- Supplementary. Extraction of quantitative features reflecting technological traits based on 3-D models of flint cores. DOI: https://doi.org/10.5334/jcaa.74.s1 


\section{ACKNOWLEDGEMENTS}

Personal thanks go to Prof. Avi Gopher, for kindly allowing us to include in the present analysis of the cores from $\mathrm{NH} \mathrm{V}$ and for his valuable comments that helped improve this paper. The authors are grateful to Prof. Gonen Sharon and Dr. Davide Visentin, for sharing their valuable insights on knapping and abrasion technique, to Antoine Muller, for providing useful editing remarks on the original draft, and to the whole staff of the Computational Archaeology Laboratory, for scanning and processing the lithic artifacts. The map in figure 1 was created using the Free and Open Source QGIS; the 3D representations in figures 3-6 and the graphs in figures 7-10 were created with Matlab $\circledast$. The present work was made possible thanks to the financial support of the ISF (1415/14 and 2034/19 to LG and 918/17 to Gonen Sharon).

\section{COMPETING INTERESTS}

The authors have no competing interests to declare.

\section{AUTHOR AFFILIATIONS}

Francesco Valletta (D) orcid.org/0000-0002-6000-1510

The Hebrew University of Jerusalem, IL

\section{Itamar Dag}

The Hebrew University of Jerusalem, IL

Leore Grosman (D) orcid.org/0000-0002-6976-6202

The Hebrew University of Jerusalem, IL

\section{REFERENCES}

Abbo, $\mathbf{S}$ and Gopher, A. 2020. Plant domestication in the Neolithic Near East: The humans-plants liaison. Quaternary Science Reviews, 242: 106412. DOI: https://doi. org/10.1016/j.quascirev.2020.106412

Agam, A, Marder, $\mathbf{O}$ and Barkai, R. 2015. Small flake production and lithic recycling at late acheulian revadim, Israel. Quaternary International, 361: 46-60. DOI: https:// doi.org/10.1016/j.quaint.2014.06.070

Andrefsky, WJ. 2005. Lithics. Cambridge: Cambridge University Press. DOI: https://doi.org/10.1017/CB09780511810244

Andrefsky, WJ. 2009. The analysis of stone tool procurement, production, and maintenance. Journal of Archaeological Research, 17(1): 65-103. DOI: https://doi.org/10.1007/ s10814-008-9026-2

Archer, W, Gunz, P, Van Niekerk, KL, Henshilwood, CS and McPherron, SP. 2015. Diachronic change within the Still Bay at Blombos Cave, South Africa. PLoS ONE, 10(7): 1-25. DOI: https://doi.org/10.1371/journal.pone.0132428

Archer, W, Pop, CM, Gunz, P and McPherron, SP. 2016. What is Still Bay? Human biogeography and bifacial point variability.
Journal of Human Evolution, 97: 58-72. DOI: https://doi. org/10.1016/j.jhevol.2016.05.007

Archer, W, Pop, CM, Rezek, Z, Schlager, S, Lin, SC, Weiss, M, Dogandžić, T, Desta, D and McPherron, SP. 2018. A geometric morphometric relationship predicts stone flake shape and size variability. Archaeological and Anthropological Sciences, 10(8): 1991-2003. DOI: https:// doi.org/10.1007/s12520-017-0517-2

Arensburg, B. 1977. New Upper Palaeolithic human remains from Israel. Eretz-Israel: Archaeological, Historical and Geographical Studies, 13: 208-215.

Arensburg, B and Bar-Yosef, 0. 1973. Human Remains from Ein Gev I, Jordan Valley, Israël. Paléorient, 1(2): 201-206. DOI: https://doi.org/10.3406/paleo.1973.4165

Assaf, E, Parush, Y, Gopher, A and Barkai, R. 2015. Intrasite variability in lithic recycling at Qesem Cave, Israel. Quaternary International, 361: 88-102. DOI: https://doi. org/10.1016/j.quaint.2014.07.071

Barkai, R and Gopher, A. 2001. Nahal Hadera V. Hadashot Arkheologiyot: Excavations and Surveys in Israel, 113: 35.

Bar-Oz, G and Dayan, T. 2002. "After 20 Years": A Taphonomic Re-evaluation of Nahal Hadera V, an Epipalaeolithic Site on the Israeli Coastal Plain. Journal of Archaeological Science, 29(2): 145-156. DOI: https://doi.org/10.1006/ jasc.2001.0684

Belfer-Cohen, A, Davidzon, A, Goring-Morris, AN, Lieberman, DE and Spiers, M. 2004. Nahal Ein Gev I: A Late Upper Palaeolithic Site by the Sea of Galilee, Israel. Paléorient, 30(1): 25-45. DOI: https://doi.org/10.3406/paleo.2004.4771

Barsky, D, Sala, R, Menéndez, L and Toro-Moyano, I. 2015. Use and re-use: Re-knapped flakes from the Mode 1 site of Fuente Nueva 3 (Orce, Andalucía, Spain). Quaternary International, 361: 21-33. DOI: https://doi.org/10.1016/j. quaint.2014.01.048

Bar-Yosef, 0. 1970. The Epi-Palaeolithic cultures of Palestine. Jerusalem: The Hebrew University of Jerusalem.

Bar-Yosef, 0. 1973. Nahal Ein Gev I, Preliminary Report. Mitekufat Haeven, 11: 1-7.

Bar-Yosef, O. 1981. The Epi-Palaeolithic Complexes in the Southern Levant. In: Cauvin, J and Sanlaville, P (eds.), Préhistoire du Levant, 389-408. Colloques. Paris: CNRS.

Belfer-Cohen, A and Goring-Morris, AN. 2002. Why Microliths? Microlithization in the Levant. Archeological Papers of the American Anthropological Association, 12(1): 57-68. DOI: https://doi.org/10.1525/ap3a.2002.12.1.57

Belfer-Cohen, A and Goring-Morris, AN. 2003. Current Issues in Levantine Upper Palaeolithic Research. In: Goring-Morris, AN and Belfer-Cohen, A (eds.), More Than Meets the Eye: Studies on Upper Palaeolithic diversity in the Near East, 1-12. Oxford: Oxbow Books. DOI: https://doi.org/10.2307/j. ctvh1dwcq.6

Belfer-Cohen, A and Goring-Morris, AN. 2014. The Upper Palaeolithic and Earlier Epi-Palaeolithic of Western Asia. In: Renfrew, C and Bahn, P (eds.), The Cambridge World Prehistory 3 Volume Set, 1381-1407. Cambridge: 
Cambridge University Press. DOI: https://doi.org/10.1017/ CH09781139017831.088

Belfer-Cohen, A and Goring-Morris, AN. 2017. The Upper Palaeolithic in Cisjordan. In: Enzel, Y and BarYosef, O (eds.), Quaternary of the Levant, 627-638. Cambridge: Cambridge University Press. DOI: https://doi. org/10.1017/9781316106754.070

Belfer-Cohen, A and Grosman, L. 2007. Tools or Cores? Carinated Artifacts in Levantine Late Upper Paleolithic Assemblages and Why Does It Matter. In: McPherron, SP (ed.), Tools versus Cores Alternative Approaches to Stone Tool Analysis, 143-163. Cambridge: Cambridge Scholars Publishing.

Bleed, P. 2001. Trees or Chains, Links or Branches: Conceptual Alternatives for Consideration of Stone Tool Production and Other Sequential Activities. Journal of Archaeological Method and Theory, 8(1): 101-127. DOI: https://doi. org/10.1023/A:1009526016167

Bocquentin, F, Crevecoeur, I, Arensburg, B, Kaufman, D and Ronen, A. 2011. Les hommes du Kébarien géométrique de Neve David, Mont Carmel (Israël). Bulletins et Memoires de la Societe d'Anthropologie de Paris, 23(1-2): 38-51. DOI: https://doi.org/10.1007/s13219-010-0032-9

Borgerhoff Mulder, M, Nunn, CL and Towner, MC. 2006. Cultural macroevolution and the transmission of traits. Evolutionary Anthropology, 15(2): 52-64. DOI: https://doi. org/10.1002/evan.20088

Brantingham, PJ. 2003. A Neutral Model of Stone Raw Material Procurement. American Antiquity, 68(3): 487-509. DOI: https://doi.org/10.2307/3557105

Brantingham, PJ. 2006. Measuring Forager Mobility. Current Anthropology, 47(3): 435-459. DOI: https://doi. org/10.1086/503062

Bretzke, K and Conard, NJ. 2012. Evaluating morphological variability in lithic assemblages using 3D models of stone artifacts. Journal of Archaeological Science, 39(12): 37413749. DOI: https://doi.org/10.1016/j.jas.2012.06.039

Byrd, BF. 1988. Late Pleistocene Settlement Diversity in the Azraq Basin. Paléorient, 14(2): 257-264. DOI: https://doi. org/10.3406/paleo.1988.4472

Byrd, BF and Garrard, AN. 2017. The Upper and Epipalaeolithic of the Azraq Basin, Jordan. In: Enzel, Y and Bar-Yosef, O (eds.), Quaternary of the Levant; Environments, Climate Change, and Humans, 669-678. Cambridge: Cambridge University Press. DOI: https://doi. org/10.1017/9781316106754.074

Byrd, BF, Garrard, AN and Brandy, P. 2016. Modeling foraging ranges and spatial organization of Late Pleistocene hunter-gatherers in the southern Levant - A least-cost GIS approach. Quaternary International, 396: 62-78. DOI: https://doi.org/10.1016/j.quaint.2015.07.048

Cavalli-Sforza, LL, Feldman, MW, Chen, KH and Dornbusch, SM. 1982. Theory and observation in cultural transmission. Science, 218(4567): 19-27. DOI: https://doi.org/10.1126/ science. 7123211
Centi, L, Groman-Yaroslavski, I, Friedman, N, Oron, M, Prévost, M and Zaidner, Y. 2019. The bulb retouchers in the Levant: New insights into Middle Palaeolithic retouching techniques and mobile tool-kit composition. PLOS ONE, 14(7): e0218859. DOI: https://doi.org/10.1371/journal. pone.0218859

Chacón, MG, Détroit, F, Coudenneau, A and Moncel, MH. 2016. Morphometric assessment of convergent tool technology and function during the early middle Palaeolithic: The case of Payre, France. PLoS ONE, 11(5): 1-20. DOI: https://doi. org/10.1371/journal.pone.0155316

Clarkson, C and Hiscock, P. 2011. Estimating original flake mass from 3D scans of platform area. Journal of Archaeological Science, 38(5): 1062-1068. DOI: https://doi. org/10.1016/j.jas.2010.12.001

Claud, É, Mourre, V, Thiébaut, C and Brenet, V. 2010. Le recyclage au Paléolithique moyen Des bifaces et des nucléus utilizes comme percuteurs. Archéopages, 29: 6-15.

Cuartero, F, Alcaraz-Castaño, M, López-Recio, M, CarriónSantafé, E and Baena-Preysler, J. 2015. Recycling economy in the mousterian of the Iberian Peninsula: The case study of El Esquilleu. Quaternary International, 361: 113-130. DOI: https://doi.org/10.1016/j.quaint.2014.11.059

Davidzon, A and Goring-Morris, AN. 2003. Sealed in stone: the upper paleolithic Early Ahmarian knapping method in the light of refitting studies at Nahal Nizzana XIII, Western Negev, Israel. Mitekufat Haeven - Journal of the Israel Prehistoric Society, 33: 75-205.

Davis, S. 1974. Animal Remains from the Kebaran Site of Ein Gev I, Jordan Valley, Israel. Paléorient, 2(2): 453-462. DOI: https://doi.org/10.3406/paleo.1974.4873

Davis, SJ, Rabinovich, R and Goren-Inbar, N. 1988. Quaternary Extinctions and Population Increase in Western Asia. Paleorient, 14(1): 95-105. DOI: https://doi.org/10.3406/ paleo.1988.4443

Delpiano, D and Uthmeier, T. 2020. Techno-functional and 3D shape analysis applied for investigating the variability of backed tools in the Late Middle Paleolithic of Central Europe. PLOS ONE, 15(8): e0236548. DOI: https://doi. org/10.1371/journal.pone.0236548

Dibble, HL. 1997. Platform Variability and Flake Morphology: A Comparison of Experimental and Archaeological Data and Implications for Interpreting Prehistoric Lithic Technological Strategies. Lithic Technology, 22(2): 150-170. DOI: https:// doi.org/10.1080/01977261.1997.11754540

Dibble, HL and Rezek, Z. 2009. Introducing a new experimental design for controlled studies of flake formation: results for exterior platform angle, platform depth, angle of blow, velocity, and force. Journal of Archaeological Science, 36(9): 1945-1954. DOI: https://doi. org/10.1016/j.jas.2009.05.004

Dubreuil, L and Nadel, D. 2015. The development of plant food processing in the Levant: insights from use-wear analysis of Early Epipalaeolithic ground stone tools. Philosophical Transactions of the Royal Society of London B: 
Biological sciences, 370(1682): 20140357. DOI: https://doi. org/10.1098/rstb.2014.0357

Edwards, PC, Macumber, PG and John Head, M. 1996. The Early Epipalaeolithic of Wadi al-Hammeh. Levant, 28: 115130. DOI: https://doi.org/10.1179/007589196790216721

Eerkens, JW and Lipo, CP. 2007. Cultural transmission theory and the archaeological record: Providing context to understanding variation and temporal changes in material culture. Journal of Archaeological Research, 15(3): 239-274. DOI: https://doi.org/10.1007/s10814-007-9013-z

Feizi, N, Vahdati Nasab, H and Wynn, T. 2018. Consider the third dimension: A new approach for measuring the symmetry of the middle Paleolithic points of the Mirak Site. Comptes Rendus - Palevol, 17(6): 388-398. DOI: https://doi. org/10.1016/j.crpv.2017.11.004

Garrard, AN and Byrd, BF. 2013. Beyond the Fertile Crescent. Late Palaeolithic and Neolithic Communities of the Jordanian Steppe. The Azraq Basin Project. Volume 1. Levant Sup. Oxford and Oakville: Oxbow Books.

Gilead, I. 1991. The Upper Paleolithic period in the Levant. Journal of World Prehistory, 5(2): 105-154. DOI: https://doi. org/10.1007/BF00974677

Gingerich, JAM, Sholts, SB, Wärmländer, SKTS and Stanford, D. 2014. Fluted point manufacture in eastern North America: An assessment of form and technology using traditional metrics and 3D digital morphometrics. World Archaeology, 46(1): 101-122. DOI: https://doi.org/10.1080/0 0438243.2014 .892437

Godfrey-Smith, DI, Vaughan, KB, Gopher, A and Barkai, R. 2003. Direct luminescence chronology of the Epipaleolithic Kebaran site of Nahal Hadera V, Israel. Geoarchaeology, 18(4): 461-475. DOI: https://doi.org/10.1002/gea.10073

Goring-Morris, AN. 1987. At the Edge. Terminal Pleistocene Hunter-Gatherers in the Negev and Sinai. Oxford: BAR Publishing. DOI: https://doi.org/10.30861/9780860544685

Goring-Morris, AN. 2009. Two Kebaran Occupations near Nahal Soreq, and the Reconstruction of Group Ranges in the Early Epipalaeolithic of the Israeli Littoral. Eurasian Prehistory, 6(1-1): 75-93.

Goring-Morris, AN and Belfer-Cohen, A. 2017. The Early and Middle Epipalaeolithic of Cisjordan. In: Enzel, Y and Bar-Yosef, O (eds.), Quaternary of the Levant: Environments, Climate Change, and Humans, 639-650. Cambridge: Cambridge University Press. DOI: https://doi. org/10.1017/9781316106754.071

Goring-Morris, AN and Davidzon, A. 2006. Straight to the point: Upper paleolithic Ahmarian lithic technology in the Levant. Anthropologie (Brno), 44(1): 93-111.

Goring-Morris, AN, Hovers, E and Belfer-Cohen, A. 2009. The dynamics of Pleistocene and Early Holocene settlement patterns and human adaptations in the Levant: an overview. In: Shea, JJ and Lieberman, DE (eds.), Transitions in Prehistory: Essays in Honor of Ofer Bar-Yosef, 185-252. American S. Oxford and Oakville: Oxbow Books.

Goring-Morris, AN, Marder, O, Davidzon, A and Ibrahim, F. 1998. Putting Humpty together again: preliminary observations on refitting studies in the eastern Mediterranean. In: Milliken, S (ed.), The organization of lithic technology in Late Glacial and early postglacial Europe, 149-182. Oxford: BAR Publishing.

Gosselain, OP. 2000. Materializing identities: An African perspective. Journal of Archaeological Method and Theory, 7(3): 187-217. DOI: https://doi. org/10.1023/A:1026558503986

Grosman, L. 2016. Reaching the Point of No Return: The Computational Revolution in Archaeology. Annual Review of Anthropology, 45(1): 129-145. DOI: https://doi.org/10.1146/ annurev-anthro-102215-095946

Grosman, L, Goldsmith, Y and Smilansky, U. 2011. Morphological analysis of Nahal Zihor handaxes: A chronological perspective. PaleoAnthropology, 203-215. DOI: https://doi.org/10.4207/PA.2011.ART53

Grosman, L, Sharon, G, Goldman-Neuman, T, Smikt, $\mathbf{O}$ and Smilansky, U. 2011. Studying post depositional damage on Acheulian bifaces using 3-D scanning. Journal of Human Evolution, 60(4): 398-406. DOI: https://doi.org/10.1016/j. jhevol.2010.02.004

Grosman, L, Smikt, $\mathbf{O}$ and Smilansky, U. 2008. On the application of 3-D scanning technology for the documentation and typology of lithic artifacts. Journal of Archaeological Science, 35(12): 3101-3110. DOI: https://doi. org/10.1016/j.jas.2008.06.011

Henry, DO. 1974. The Utilization of the Microburin Technique in the Levant. Paléorient, 2(2): 389-398. DOI: https://doi. org/10.3406/paleo.1974.1058

Herzlinger, G and Goren-Inbar, N. 2019a. Beyond a Cutting Edge: a Morpho-technological Analysis of Acheulian Handaxes and Cleavers from Gesher Benot Ya'aqov, Israel. Journal of Paleolithic Archaeology. DOI: https://doi. org/10.1007/s41982-019-00033-5

Herzlinger, G and Goren-Inbar, N. 2019b. Do a few tools necessarily mean a few people? A techno-morphological approach to the question of group size at Gesher Benot Ya'aqov, Israel. Journal of Human Evolution, 128: 45-58. DOI: https://doi.org/10.1016/j.jhevol.2018.11. 008

Hiscock, P. 2009. Reduction, Recycling, and Raw Material Procurement in Western Arnhem Land, Australia. In: Adams, B and Blades, BS (eds.), Lithic Materials and Paleolithic Societies, 78-93. Oxford: Wiley-Blackwell. DOI: https://doi.org/10.1002/9781444311976.ch6

Hiscock, P. 2014. Learning in Lithic Landscapes: A Reconsideration of the Hominid "Toolmaking" Niche. Biological Theory, 9(1): 27-41. DOI: https://doi.org/10.1007/ s13752-013-0158-3

Hiscock, P. 2015. Recycling in the haua fteah sequence of North Africa. Quaternary International, 361: 251-255. DOI: https://doi.org/10.1016/j.quaint.2014.08.028

Hovers, E. 1990. Art in the Levantine Epi-Palaeolithic: An Engraved Pebble from a Kebaran Site in the Lower Jordan Valley. Current Anthropology, 31(3): 317-322. DOI: https:// doi.org/10.1086/203845 
Hussain, ST. 2015. Betwixt seriality and sortiment: Rethinking early Ahmarian blade technology in Al-Ansab 1. In: Schyle, D and Richter, J (eds.), Pleistocene Archaeology of the Petra Area in Jordan, 131-147. Band 5. Leidorf: Kölner Studien zur Prähistorischen archäologie.

Jacquier, J and Naudinot, N. 2015. Socio economic significance of stone tools recycling, reuse and maintenance at the end of the Lateglacial in Northwestern France. Quaternary International, 361: 269-287. DOI: https://doi.org/10.1016/j. quaint.2014.09.051

Kadowaki, S and Nishiaki, Y. 2016. New Epipalaeolithic assemblages from the middle Euphrates and the implications for technological and settlement trends in the northeastern Levant. Quaternary International, 396: 121 137. DOI: https://doi.org/10.1016/j.quaint.2015.06.014

Kaufman, D, Groman-Yaroslavski, I, Yeshurun, R, CraterGershtein, E and Nadel, D. 2017. Engraved flint nodules from the Levantine middle Epipaleolithic: Neve David revisited. Quaternary International, 1-18. DOI: https://doi. org/10.1016/j.quaint.2017.06.037

Lemorini, C, Venditti, F, Assaf, E, Parush, Y, Barkai, R and Gopher, A. 2015. The function of recycled lithic items at late Lower Paleolithic Qesem Cave, Israel: An overview of the use-wear data. Quaternary International, 361: 103-112. DOI: https://doi.org/10.1016/j.quaint.2014.07.032

Lin, SC, Rezek, Z, Braun, D and Dibble, HL. 2013. On the Utility and Economization of Unretouched Flakes: the Effects of Exterior Platform Angle and Platform Depth. American Antiquity, 78(4): 724-745. DOI: https://doi. org/10.7183/0002-7316.78.4.724

Lombao, D, Cueva-Temprana, A, Mosquera, M and Morales, JI. 2020. A new approach to measure reduction intensity on cores and tools on cobbles: the Volumetric Reconstruction Method. Archaeological and Anthropological Sciences, 12(9). DOI: https://doi.org/10.1007/s12520-020-01154-7

Lombao, D, Cueva-Temprana, A, Rabuñal, JR, Morales, JI and Mosquera, M. 2019. The effects of blank size and knapping strategy on the estimation of core's reduction intensity. Archaeological and Anthropological Sciences, 11(10): 54455461. DOI: https://doi.org/10.1007/s12520-019-00879-4

Lycett, SJ and Von Cramon-Taubadel, N. 2013. A 3D morphometric analysis of surface geometry in Levallois cores: Patterns of stability and variability across regions and their implications. Journal of Archaeological Science, 40(3): 1508-1517. DOI: https://doi.org/10.1016/j.jas.2012.11.005

Lyman, RL and O'Brien, MJ. 2003. Cultural traits: Units of analysis in early twentieth-century anthropology. Journal of Anthropological Research, 59(2): 225-250. DOI: https://doi. org/10.1086/jar.59.2.3631642

Macdonald, DA. 2013. Interpreting Variability Through Multiple Methodologies: The Interplay of Form and Function in Epipalaeolithic Microliths. Toronto: University of Toronto.

Machin, A. 2009. The role of the individual agent in Acheulean biface variability: A multi-factorial model. Journal of Social Archaeology, 9(1): 35-58. DOI: https://doi. org/10.1177/1469605308099370
Magnani, M, Rezek, Z, Lin, SC, Chan, A and Dibble, HL. 2014. Flake variation in relation to the application of force. Journal of Archaeological Science, 46(1): 37-49. DOI: https://doi.org/10.1016/j.jas.2014.02.029

Maher, LA, Richter, T and Stock, JT. 2012. The Pre-Natufian Epipaleolithic: Long-term Behavioral Trends in the Levant. Evolutionary Anthropology, 21(2): 69-81. DOI: https://doi. org/10.1002/evan.21307

Maher, LA, Stock, JT, Finney, S, Heywood, JJN, Miracle, PT and Banning, EB. 2011. A Unique Human-Fox Burial from a PreNatufian Cemetery in the Levant (Jordan). PLoS ONE, 6(1): 1-10. DOI: https://doi.org/10.1371/journal.pone.0015815

Marder, 0. 2002. The lithic technology of Epipaleolithic huntergatherers in the Negev: the implication of refitting studies. Jerusalem: Hebrew University of Jerusalem.

Marom, $\mathbf{N}$ and Bar-Oz, G. 2008. 'Measure for measure': a taphonomic reconsideration of the Kebaran site of Ein Gev I, Israel. Journal of Archaeological Science, 35(2): 214-227. DOI: https://doi.org/10.1016/j.jas.2007.03.004

Martin, G and Bar-Yosef, 0. 1975. Ein Gev III, Israel (1974-1975). Paléorient, 3: 285-286. DOI: https://doi. org/10.3406/paleo.1975.4210

Martin, G and Bar-Yosef, O. 1979. Ein-Gev III, Israël (1978). Paléorient, 5: 219-220. DOI: https://doi.org/10.3406/ paleo.1979.4249

Marwick, B. 2008. What attributes are important for the measurement of assemblage reduction intensity? Results from an experimental stone artefact assemblage with relevance to the Hoabinhian of mainland Southeast Asia. Journal of Archaeological Science, 35(5): 1189-1200. DOI: https://doi.org/10.1016/j.jas.2007.08.007

Morales, JI, Lorenzo, C and Vergès, JM. 2015. Measuring Retouch Intensity in Lithic Tools: A New Proposal Using 3D Scan Data. Journal of Archaeological Method and Theory, 22: 543-558. DOI: https://doi.org/10.1007/s10816-0139189-0

Muller, A and Clarkson, C. 2014. Estimating original flake mass on blades using 3D platform area: Problems and prospects. Journal of Archaeological Science, 52: 31-38. DOI: https:// doi.org/10.1016/j.jas.2014.08.025

Muller, A and Clarkson, C. 2016. Identifying Major Transitions in the Evolution of Lithic Cutting Edge Production Rates. Macchiarelli, R (ed.), PLOS ONE, 11(12): e0167244. DOI: https://doi.org/10.1371/journal.pone.0167244

Munro, ND. 2009a. Epipaleolithic Subsistence Intensification in the Southern Levant: The Faunal Evidence. In: Hublin, J-J and Richards, MP (eds.), The Evolution of Hominin Diets: Integrating Approaches to the Study of Palaeolithic Subsistence, 141-155. Dordrecht: Springer. DOI: https://doi. org/10.1007/978-1-4020-9699-0_10

Munro, ND. 2009b. Integrating inter- \& intra-site analyses of Epipalaeolithic faunal assemblages from Israel. Before Farming, 1(4): 1-18. DOI: https://doi.org/10.3828/ bfarm.2009.1.4

Munro, ND, Bar-Oz, G, Meier, JS, Sapir-Hen, L, Stiner, MC and Yeshurun, R. 2018. The Emergence of Animal Management 
in the Southern Levant. Scientific Reports, 8(1): 1-11. DOI: https://doi.org/10.1038/s41598-018-27647-z

Nadel, D, Piperno, DR, Holst, I, Snir, A and Weiss, E. 2012. New evidence for the processing of wild cereal grains at Ohalo II, a 23 000-year-old campsite on the shore of the Sea of Galilee, Israel. Antiquity, 86(334): 990-1003. DOI: https:// doi.org/10.1017/S0003598X00048201

Nelson, M. 1991. The study of technological organization, Archaeological Method and Theory, 3: 57-100.

Parush, Y, Assaf, E, Slon, V, Gopher, A and Barkai, R. 2015. Looking for sharp edges: Modes of flint recycling at Middle Pleistocene Qesem Cave, Israel. Quaternary International, 361: 61-87. DOI: https://doi.org/10.1016/j. quaint.2014.07.057

Pelegrin, J. 2000. Les techniques de débitage laminaire au Tardiglaciaire: critères de diagnose et quelques réflexions. In: Valentin, B, Bodu, P and Christensen, M (eds.), L'Europe centrale et septentrionale au tardiglaciaire, 73-86. Nemours: A.P.R.A.I.F.

Pop, CM. 2016. Simulating Lithic Raw Material Variability in Archaeological Contexts: A Re-evaluation and Revision of Brantingham's Neutral Model. Journal of Archaeological Method and Theory, 23(4): 1127-1161. DOI: https://doi. org/10.1007/s10816-015-9262-y

Porter, ST, Roussel, M and Soressi, M. 2019. A Comparative Analysis of Châtelperronian and Protoaurignacian Blade Core Technology Using Data Derived from 3D Models. Journal of Computer Applications in Archaeology, 2(1): 41-55. DOI: https://doi.org/10.5334/jcaa.17

Premo, LS and Tostevin, GB. 2016. Cultural transmission on the taskscape: Exploring the effects of taskscape visibility on cultural diversity. PLOS ONE, 11(9): 1-22. DOI: https://doi. org/10.1371/journal.pone.0161766

Presnyakova, D, Braun, DR, Conard, NJ, Feibel, C, Harris, JWK, Pop, CM, Schlager, S and Archer, W. 2018. Site fragmentation, hominin mobility and LCT variability reflected in the early Acheulean record of the Okote Member, at Koobi Fora, Kenya. Journal of Human Evolution, 125: 159-180. DOI: https://doi.org/10.1016/j. jhevol.2018.07.008

Ranhorn, KL, Braun, DR, Biermann Gürbüz, RE, Greiner, E, Wawrzyniak, D and Brooks, AS. 2019. Evaluating prepared core assemblages with three-dimensional methods: a case study from the Middle Paleolithic at Skhūl (Israel). Archaeological and Anthropological Sciences, 11(7): 32253238. DOI: https://doi.org/10.1007/s12520-018-0746-z

Rezek, Z, Lin, S, Iovita, R and Dibble, HL. 2011. The relative effects of core surface morphology on flake shape and other attributes. Journal of Archaeological Science, 38(6): 1346-1359. DOI: https://doi.org/10.1016/j. jas.2011.01.014

Richardson, E, Grosman, L, Smilansky, U and Werman, M. 2013. Extracting Scar and Ridge Features from 3D-scanned Lithic Artifacts. In: Earl, G, Sly, T, Chrysanti, A, Murrieta-Flores, P, Papadopoulos, C, Romanowska, I and
Wheatley, D (eds.), Archaeology in the Digital Era, 83-92. Amsterdam: Amsterdam University Press. DOI: https://doi. org/10.1515/9789048519590-010

Rios-Garaizar, J, Eixea, A and Villaverde, V. 2015. Ramification of lithic production and the search of small tools in Iberian Peninsula Middle Paleolithic. Quaternary International, 361 : 188-199. DOI: https://doi.org/10.1016/j.quaint.2014.07.025

Rosenberg, M. 1990. The Mother of Invention: Evolutionary Theory, Territoriality, and the Origins of Agriculture. American Anthropologist, 92(2): 399-415. DOI: https://doi. org/10.1525/aa.1990.92.2.02a00090

Rosenberg, M. 1998. Cheating at musical chairs: Territoriality and sedentism in an evolutionary context. Current Anthropology, 39(5): 653-681. DOI: https://doi. org/10.1086/204787

Sackett, JR. 1982. Approaches to style in lithic archaeology. Journal of Anthropological Archaeology, 1(1): 59-112. DOI: https://doi.org/10.1016/0278-4165(82)90008-3

Sackett, JR. 1986. Isochrestism and style: A clarification. Journal of Anthropological Archaeology, 5(3): 266-277. DOI: https://doi.org/10.1016/0278-4165(86)90008-5

Saxon, EC, Martin, G and Bar-Yosef, 0. 1978. Nahal Hadera V: an Open-air Site on the Israeli Littoral. Paléorient, 4: 253266. DOI: https://doi.org/10.3406/paleo.1978.4229

Shea, JJ and Klenck, JD. 1993. An Experimental Investigation of the Effects of Trampling on the Results of Lithic Microwear Analysis. Journal of Archaeological Science, 20(2): 175-194. DOI: https://doi.org/10.1006/ jasc.1993.1013

Sheets, PD. 1973. Edge Abrasion during Biface Manufacture. American Antiquity, 38(2): 215-218. DOI: https://doi. org/10.2307/279370

Shimelmitz, R. 2002. Technological Aspects of the Flint Industry from the Kebaran Site Nahal Hadera V. Tel Aviv: Tel Aviv University.

Shimelmitz, R. 2015. The recycling of flint throughout the lower and middle paleolithic sequence of tabun cave, Israel. Quaternary International, 361: 34-45. DOI: https://doi. org/10.1016/j.quaint.2014.08.033

Shimelmitz, R, Friesem, DE, Clark, JL, Groman-Yaroslavski, I, Weissbrod, L, Porat, N and Kandel, AW. 2018. The Upper Paleolithic and Epipaleolithic of Sefunim Cave, Israel. Quaternary International, 464: 106-125. DOI: https://doi. org/10.1016/j.quaint.2017.05.039

Sholts, SB, Gingerich, JAM, Schlager, S, Stanford, DJ and Wärmländer, SKTS. 2017. Tracing social interactions in Pleistocene North America via 3D model analysis of stone tool asymmetry. PLoS ONE, 12(7): 1-18. DOI: https://doi. org/10.1016/j.quaint.2014.08.033

Sholts, SB, Stanford, DJ, Flores, LM and Wärmländer, SKTS. 2012. Flake scar patterns of Clovis points analyzed with a new digital morphometrics approach: Evidence for direct transmission of technological knowledge across early North America. Journal of Archaeological Science, 39(9): 3018-3026. DOI: https://doi.org/10.1016/j.jas.2012.04.049 
Shott, MJ. 2003. Chaîne Opératoire and Reduction Sequence. Lithic Technology, 28(2): 95-105. DOI: https://doi.org/10.10 80/01977261.2003.11721005

Shott, MJ and Trail, BW. 2010. Exploring New Approaches to Lithic Analysis: Laser Scanning and Geometric Morphometrics. Lithic Technology, 35(2): 195-220. DOI: https://doi.org/10.1080/01977261.2010.11721090

Snir, A, Nadel, D, Groman-Yaroslavski, I, Melamed, Y, Sternberg, M, Bar-Yosef, $\mathbf{O}$ and Weiss, E. 2015. The origin of cultivation and proto-weeds, long before neolithic farming. PLOS ONE, 10(7): 1-12. DOI: https://doi. org/10.1371/journal.pone.0131422

Soressi, M and Geneste, J-M. 2011. The history and the efficacy of the chaîne opératoire approach to lithic analysis: Studying Techniques to Reveal Past Societies in an Evolutionary Perspective. PaleoAnthropology, 334-350. November. DOI: https://doi.org/10.4207/PA.2011.ART63

Speth, JD. 1972. Mechanical Basis of Percussion Flaking. American Antiquity, 37(1): 34-60. DOI: https://doi. org/10.2307/278884

Stiner, MC. 2001. Thirty years on the 'Broad Spectrum Revolution' and paleolithic demography. Proceedings of the National Academy of Sciences of the United States of America, 98(13): 6993-6996. DOI: https://doi.org/10.1073/ pnas. 121176198

Stiner, MC, Munro, ND and Surovell, TA. 2000. The Tortoise and the Hare: Small-Game Use, the Broad-Spectrum Revolution, and Paleolithic Demography. Current Anthropology, 41(1): 39. DOI: https://doi.org/10.2307/3596428

Stuiver, M, Reimer, PJ and Reimer, RW. 2021. CALIB 8.2 [WWW program] at http://calib.org [accessed 21/5/21].

Stutz, AJ, Munro, ND and Bar-Oz, G. 2009. Increasing the resolution of the Broad Spectrum Revolution in the Southern Levantine Epipaleolithic (19-12 ka). Journal of Human Evolution, 56(3): 294-306. DOI: https://doi. org/10.1016/j.jhevol.2008.10.004

Tixier, J. 1967. Procedes d'analyse et questions de terminologie concernant l'etude des ensembles industriels du Paleolithique recent et de l'Epipaleolithique dans l'Afrique du nord-ouest. In: Bishop, WW and Clark, JD (eds.), Background to evolution in África (Bishop \& Clarks), 771-820. Chicago and London: The University of Chicago Press.

Tostevin, GB. 2011. Levels of Theory and Social Practice in the Reduction Sequence and Chaîne Opératoire Methods of Lithic Analysis. PaleoAnthropology, 351-375. DOI: https:// doi.org/10.4207/PA.2011.ART64

Trinkaus, E. 2018. Epipaleolithic human appendicular remains from Ein Gev I, Israel. Comptes Rendus - Palevol, 17(8): 616-627. DOI: https://doi.org/10.1016/j.crpv.2018.03.002

Valletta, F and Grosman, L. 2021. Local Technological Traditions in the Early and Middle Epipaleolithic of Ein Gev Area. Journal of Paleolithic Archaeology, 4(2): 10. DOI: https://doi.org/10.1007/s41982-021-00079-4

Valletta, F, Smilansky, U, Goring-Morris, AN and Grosman, L. 2020. On measuring the mean edge angle of lithic tools based on 3-D models - a case study from the southern Levantine Epipalaeolithic. Archaeological and Anthropological Sciences, 12(2): 49. DOI: https://doi. org/10.1007/s12520-019-00954-w

Vaquero, M, Bargalló, A, Chacón, MG, Romagnoli, F and Sañudo, P. 2015. Lithic recycling in a middle paleolithic expedient context: Evidence from the Abric Romaní (Capellades, Spain). Quaternary International, 361: 212228. DOI: https://doi.org/10.1016/j.quaint.2014.05.055

Vaquero, M, Chacón, MG, García-Antón, MD, Gómez de Soler, B, Martínez, K and Cuartero, F. 2012. Time and space in the formation of lithic assemblages: The example of Abric Romaní Level J. Quaternary International, 247(1): 162-181. DOI: https://doi.org/10.1016/j.quaint.2010.12.015

Viallet, C. 2019. A new method of three-dimensional morphometry for analyzing the functional potentialities of bifaces. Contribution to the study of artefacts from AU P3 from the "Caune de l'Arago" (France). Comptes Rendus - Palevol, 18(2): 236-250. DOI: https://doi.org/10.1016/j. crpv.2018.11.001

Weiss, M, Lauer, T, Wimmer, R and Pop, CM. 2018. The Variability of the Keilmesser-Concept: a Case Study from Central Germany. Journal of Paleolithic Archaeology, 1(3): 202-246. DOI: https://doi.org/10.1007/s41982-018-00 $13-y$

Wilcoxon, F. 1945. Individual Comparisons by Ranking Methods. Biometric Bullettin, 1(6): 80-83. DOI: https://doi. org/10.1093/jee/39.2.269

Wilcoxon, F. 1946. Individual Comparisons of Grouped Data by Ranking Methods. Journal of economic entomology, 39 : 269. April. DOI: https://doi.org/10.1093/jee/39.2.269

Wobst, HM. 1977. Stylistic behavior and information exchange. In: Cleland, CE (ed.), For the Director: Research Essays in Honor of James B, 317-342. Griffin. Ann Arbor: University of Michigan Museum of Anthropology.

Wojtczak, D. 2015. Cores on flakes and bladelet production, a question of recycling? Theperspective from the Hummalian industry of Hummal, Central Syria. Quaternary International, 361: 155-177. DOI: https://doi.org/10.1016/j. quaint.2014.10.021

Yaroshevich, A, Bar-Yosef, O, Boaretto, E, Caracuta, V, Greenbaum, N, Porat, N and Roskin, J. 2016. A Unique Assemblage of Engraved Plaquettes from Ein Qashish South, Jezreel Valley, Israel: Figurative and Non-Figurative Symbols of Late Pleistocene Hunters-Gatherers in the Levant. Plos One, 11(8): e0160687. DOI: https://doi. org/10.1371/journal.pone.0160687

Zaidner, Y and Grosman, L. 2015. Middle Paleolithic sidescrapers were resharped or recycled? A view from Nesher Ramla, Israel. Quaternary International, 361: 178-187. DOI: https://doi.org/10.1016/j.quaint.2014.11.037

Zeder, MA. 2012. The Broad Spectrum Revolution at 40: Resource diversity, intensification, and an alternative to optimal foraging explanations. Journal of Anthropological Archaeology, 31(3): 241-264. DOI: https://doi.org/10.1016/j.jaa.2012.03.003 
TO CITE THIS ARTICLE:

Valletta, F, Dag, I and Grosman, L. 2021. Identifying Local Learning Communities During the Terminal Palaeolithic in the Southern Levant: Multi-scale 3-D Analysis of Flint Cores. Journal of Computer Applications in Archaeology, 4(1): 145-168. DOI: https://doi. org/10.5334/jcaa.74

Submitted: 22 March 2021 Accepted: 18 June $2021 \quad$ Published: 28 July 2021

COPYRIGHT:

(c) 2021 The Author(s). This is an open-access article distributed under the terms of the Creative Commons Attribution 4.0 International License (CC-BY 4.0), which permits unrestricted use, distribution, and reproduction in any medium, provided the original author and source are credited. See http://creativecommons.org/licenses/by/4.0/.

Journal of Computer Applications in Archaeology is a peer-reviewed open access journal published by Ubiquity Press.

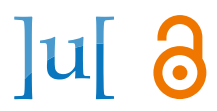

